\title{
Effect of tidal resuspension on benthic-pelagic coupling in an experimental ecosystem study
}

\author{
Elka T. Porter, ${ }^{1, *}$ Robert P. Mason ${ }^{2}$, Lawrence P. Sanford ${ }^{3}$ \\ ${ }^{1}$ Washington College, Department of Biology, 300 Washington Avenue, Chestertown, Maryland 21620, USA \\ ${ }^{2}$ University of Connecticut, Department of Marine Sciences, 1080 Shennecossett Road, Groton, Connecticut 06340, USA \\ ${ }^{3}$ University of Maryland Center for Environmental Science, Horn Point Laboratory, 2020 Horns Point Rd, PO Box 775 , \\ Cambridge, Maryland 21613, USA
}

\begin{abstract}
To test the effect of sediment resuspension on the nutrient and ecosystem dynamics we performed a $4 \mathrm{wk}$ experiment in three $1000 \mathrm{l}$ shear-turbulence-resuspension-mesocosm (STURM) resuspension (R) tanks and three $1000 \mathrm{l}$ non-resuspension (NR) tanks. All tanks contained defaunated muddy sediment and brackish estuarine water and had similar water-column turbulence intensities $\left(\sim 1 \mathrm{~cm} \mathrm{~s}^{-1}\right)$, energy dissipation rates $\left(\sim 0.08 \mathrm{~cm}^{2} \mathrm{~s}^{-3}\right)$, and tidal cycles $(4 \mathrm{~h}$ mixing-on and $2 \mathrm{~h}$ mixingoff). However, while bottom shear velocity (stress) was low in the NR tanks, high instantaneous bottom shear produced resuspension in the $\mathrm{R}$ tanks during the mixing-on cycles. Tidal resuspension in the $\mathrm{R}$ tanks resulted in concentrations of 120 to $220 \mathrm{mg} \mathrm{l}^{-1}$ total suspended solids when mixing was on, decreasing to between 10 and $20 \mathrm{mg} \mathrm{l}^{-1}$ when mixing was off. Particulate nitrogen, phosphorus, and carbon concentrations, as well as dissolved inorganic nitrogen, nitrate + nitrite, and phosphate levels were higher in the R tanks. Phytoplankton biomass was also higher in the R tanks, though light was limiting. Tidal resuspension affected water-column algal and zooplankton community composition and induced significantly higher concentrations of brown tide Aureococcus anophagefferens. Microphytobenthos biomass was significantly higher in the NR tanks. Dissolved inorganic nitrogen sediment effluxes were similar in both tanks; however, polychaetes and amphipods developed in the NR, but not in the R tank sediments. Tidal resuspension shifted processes from the benthos to the water column. Regular tidal resuspension profoundly affected ecosystem structure and function, often through indirect pathways and linkages.
\end{abstract}

KEY WORDS: Tidal resuspension $\cdot$ Benthic-pelagic coupling $\cdot$ Shear stress $\cdot$ Shear velocity $\cdot$ STURM Ecosystem Resale or republication not permitted without written consent of the publisher

\section{INTRODUCTION}

Sediment resuspension is ubiquitous in shallowwater environments where the water-column and benthic environments are closely coupled. Wind and storm events (Schoellhamer 1995), tides (Sanford et al. 1991), waves (Guillén et al. 2002), or wave-current interactions (Grant \& Madsen 1979) result in sediment resuspension and high water-column turbidity, with temporal changes in seston quantity and quality. Physical forcing of sediment resuspension can be expressed in terms of the time history of applied bottom shear stress, $\tau_{\mathrm{b}}$ (units of dynes $\mathrm{cm}^{-2}$ or Pa). A related parameter is the shear (or 'friction') velocity, defined as $u_{*}=\sqrt{\tau_{b} / \rho}$, (in $\mathrm{cm} \mathrm{s}^{-1}$ or $\left.\mathrm{m} \mathrm{s}^{-1}\right)$, where $\rho$ is the water density (in $\mathrm{g} \mathrm{cm}^{-3}$ or $\mathrm{kg} \mathrm{m}^{-3}$ ). Seston concentrations due to resuspension in low to moderately energetic tidal estuaries range from $40 \mathrm{mg} \mathrm{l}^{-1}$ (northern Chesapeake Bay [Sanford et al. 1991]) to 100s of milligrams per liter (e.g. $300 \mathrm{mg} \mathrm{l}^{-1}$ during storms, Tampa Bay [Schoellhamer 1995], $600 \mathrm{mg} \mathrm{l}^{-1}$, Hudson River [Heyes et al. 2004], and $1500 \mathrm{mg} \mathrm{l}^{-1}$, San Francisco Bay [Schoellhamer 2002]). The yearly average of the total suspended seston levels in the Mississippi River over a 
29 yr period ending in the mid-1990s was $360 \mathrm{mg} \mathrm{l}^{-1}$ (Trefry et al. 1994), and suspended seston concentrations in other rivers can be even higher (Meybeck et al. 2003).

The critical erosion shear velocity, $u_{*_{\mathrm{c}}}$ (or stress $\tau_{\mathrm{c}}$ ) represents the level of applied forcing at which sediment is first resuspended. It is a sediment bed property that can be affected by the time history of resuspension and deposition (Sanford 2008) and/or by the composition of the benthos (Davis 1993). Sediments that are frequently disturbed by resuspension and subsequent deposition remain unconsolidated and relatively easy to erode (Sanford 2008). Macrofauna change sediment erodibility through adhesive-cohesive bonding among particles (Blanchard et al. 1997) and by influencing the sediment water content, which indirectly affects $\tau_{\mathrm{c}}$ (Aberle et al. 2004). Polychaetes and amphipods alter the sediment water content and enhance or decrease sediment stability through the type and composition of their burrow structures (Meadows \& Tait 1989). Mucus secreted by organisms influences sediment cohesiveness (Blanchard et al. 1997) and thus sediment erodibility. High densities of organisms such as infaunal clams have been shown to increase sediment erodibility in short-term flume experiments (Willows et al. 1998).

Microphytobenthos can stabilize or destabilize sediment. Polysaccharide matrices caused by diatom movements or webs of cyanobacteria stabilize sediment and reduce resuspension (Yallop et al. 1994). However, microphytobenthos can also destabilize sediment as the mat ages due to bubble formation within the mat (Porter et al. 2004b). In ecosystems, the biomass of microphytobenthos is mediated by both the light that reaches the bottom and bottom shear (MacIntyre et al. 1996, Porter et al. 2004a, b), as sediment resuspension alters the benthic light environment. Microphytobenthos can also reduce nutrient regeneration from the sediments (Sundbäck et al. 2000) and provide food for macrofaunal filter and deposit feeders (Muschenheim \& Newell 1992, Herman et al. 2000).

It is difficult to discern cause-effect relationships within natural shallow ecosystems from in situ measurements due to uncontrollable variability and feedbacks. As a result, many researchers turn to benchscale process studies. Process studies investigating sediment resuspension have been done in erosion devices such as annular flumes (Maa et al. 1998), microcosms (Gust \& Müller 1997, Thomsen \& Gust 2000), EROMES chambers (Andersen 2001), and particle entrainment simulators (Tsai \& Lick 1986). These investigations have generated a great deal of information on the effects of sediment type, organisms, and microphytobenthos on sediment erodibility. In addition, process studies with resuspended sediments in beakers (Fanning et al. 1982) and in benthic chambers with oscillating grids (Garstecki et al. 2002) have been used to examine ammonium release from particles or from porewater.

Such small-scale process studies have shown that resuspension affects various water-column processes. Resuspension can stimulate nutrient regeneration and affect water-column nutrients, potentially due to porewater resuspension (Fanning et al. 1982) or release of nutrients from particles. For example, Morin \& Morse (1999) resuspended particles in beakers and found that ammonium was released from the particles. Similarly, resuspension in lakes increased phosphate fluxes according to Sondergaard et al. (1992). Using a combination of in situ benthic chamber and field measurements, Tengberg et al. (2003) showed that resuspension also affected organic carbon cycling and nutrient exchanges, as well as decreased water-column dissolved oxygen concentrations in a Danish estuary. In addition, sediment resuspension can increase bacterial growth (Wainright 1990) and affect the coastal planktonic microbial food web (Garstecki et al. 2002).

Ecosystem models with realistic water-column mixing and bottom shear stress predict that porewater and sediment resuspension release nutrients and contaminants into the water column (Wainright \& Hopkinson 1997, Chang \& Sanford 2005). However, to be predictive, such models need data from whole-ecosystem experiments that capture the direct and indirect interactions of the physical, biological, and chemical components in the ecosystem. The microphytobenthos, for example, is an important aspect of shallow-water environments, and its growth is mediated by both light and bottom shear (Porter et al. 2004a, b). Blackford (2002) considered the microphytobenthos in his ecosystem model, but used only light to mediate the microphytobenthos and not bottom shear. MacIntyre et al. (2004) put forward a hypothetical model, which included microphytobenthos and resuspension in the context of harmful algal blooms, but data to support the model predictions are sparse.

Natural ecosystems are fundamentally complex and encompass many direct and indirect interactions. Direct interactions have been defined as the direct effects of one process on another (Krivtsov 2004) or the effect of one species on another that does not involve a third species (Montoya et al. 2006). Indirect interactions have been defined as interaction modifications that only become apparent when multiple species (or multiple environmental influences) are combined (Wootton 2002). Indirect effects often are non-additive, such that the total does not equal the sum of the parts (Jørgensen et al. 1992). Thus, indirect interactions cannot be predicted by linear extrapolation from single or dual species experiments, but require the complexity 
of a mesocosm or a field experiment (Wootton 2002, Porter et al. 2004a,b). For example, Porter et al. (2004b) found that oyster feeding increased both light at the bottom and microphytobenthos biomass (direct effects). However, bottom shear eroded the microphytobenthos, thus reducing the microphytobenthos' positive effects on water quality (an indirect effect). Such indirect effects cannot be easily tracked in nature and have not been sufficiently explored. Whole-ecosystem approaches are needed to track key ecosystem processes and their interactions, especially in shallow water settings where benthic-pelagic coupling is important.

To study the effect of bottom shear on sediment resuspension and benthic-pelagic coupling processes in a controllable whole-ecosystem context, we used 10001 experimental ecosystems, containing estuarine sediment and water. All tanks had the same levels of water-column turbulence but different levels of bottom shear velocity, resulting in either an approximation of tidal resuspension (R) or non-resuspension (NR). The NR tanks had been used in previous ecosystem experiments without sediment resuspension at the Multiscale Experimental Ecosystem Research Center (MEERC) at the Horn Point Laboratory in Cambridge, Maryland. The specific questions we sought to address with the $\mathrm{R}$ and NR tanks during a month-long experiment were: How does tidal resuspension affect water quality, microphytobenthos, and meso-zooplankton dynamics, and are these effects produced through direct interactions or indirect interactions associated with complexity?

\section{MATERIALS AND METHODS}

Physical scaling in experimental ecosystems. We used 2 sets of triplicate cylindrical tanks, the shear-turbulence-resuspension-mesocosm (STURM) resuspension tanks (Schneider et al. 2007, who use the designation STORM tanks), and standard non-resuspension MEERC tanks (termed 'C tanks' in Crawford \& Sanford 2001). The $R$ tanks had a single paddle (Fig. 1) to induce high bottom shear stresses, which resuspended sediments without overstirring the water column. The paddle configuration and mixing configuration in the NR tanks produced unrealistically low shear stress at the bottom and no sediment resuspension (Porter et al. 2004a). The paddle speeds and the forward-stop-backward motion of the R and NR mixing paddles were set to produce similar tank-averaged turbulence intensities and energy dissipation rates between the NR and $\mathrm{R}$ tanks, however. All tanks had a $1 \mathrm{~m}$ deep water column, a $1000 \mathrm{l}$ volume and a $1 \mathrm{~m}^{2}$ sediment surface area, with a $10 \mathrm{~cm}$ layer of muddy sediment at the bot- tom (Fig. 1). The R tanks are the successor design of the large linked mesocosms of Porter et al. (2004a,b) and were used at the Chesapeake Biological Laboratory in Solomons, Maryland. The NR tanks were also used in ecosystem experiments at MEERC at the Horn Point Laboratory in Cambridge, Maryland. The R and the NR tanks had the same tidal cycle approximations of $4 \mathrm{~h}$ mixing-on and $2 \mathrm{~h}$ mixing-off over a $4 \mathrm{wk}$ experiment. In these experiments, R and NR tanks primarily differed in terms of the amount of bottom shear that was applied, i.e. the factor that governs resuspension of bottom sediments.

The different paddle and mixing configurations in the NR and R tanks produced water-column turbulence. To determine water-column turbulence intensities, we used a combination of gypsum dissolution techniques (as appropriate in certain flow conditions; Porter et al. 2000) and direct flow and turbulence measurements with an acoustic Doppler velocimeter (ADV) at different mixing speeds at a number of representative locations in the NR and R tanks following techniques described by Porter et al. (2004a). An ADV was used for all turbulence measurements in the $\mathrm{R}$ tanks. Turbulence intensity is defined by Tennekes \& Lumley (1972) as:

$$
q=\sqrt{\frac{1}{3}\left(<u^{2}>+<v^{2}>+<w^{2}>\right)}
$$

where $\left\langle u^{2}\right\rangle,\left\langle v^{2}\right\rangle$, and $\left\langle w^{2}\right\rangle$ are the variances of their respective velocity components. Energy dissipation rates were determined following Sanford (1997). Water-column turbulence characteristics were similar in all systems, with volume-weighted average turbulence intensities of about $1.08 \mathrm{~cm} \mathrm{~s}^{-1}$ (Fig. 1a,b) and volume-weighted average energy dissipation rates of about $0.08 \mathrm{~cm}^{2} \mathrm{~s}^{-3}$ when mixing was on (Fig. 1c,d). Turbulence intensities of $1 \mathrm{~cm} \mathrm{~s}^{-1}$ are at the lower end of intensities in natural estuaries. These turbulence levels were used because they still allowed energy dissipation rates in the systems to be held down to reasonable levels. Turbulence intensities of about $1 \mathrm{~cm} \mathrm{~s}^{-1}$ had also been used in previous experiments in NR tanks of the same shape, size, and mixing design at MEERC, e.g. as in experiments with different watercolumn mixing levels, but with low bottom shear stress and no resuspension (Petersen et al. 1998).

We quantified benthic shear stress in the $\mathrm{R}$ tanks directly using hot film anemometry (Gust 1988). Instantaneous bottom shear stresses were as high as 0.35 to 0.4 $\mathrm{Pa}$ in the $\mathrm{R}$ tanks, such that sediment resuspension was induced during the mixing-on phases (Fig. 1f). Bottom shear stress was low at $\sim 0.001 \mathrm{~Pa}$ in the NR tanks (Crawford \& Sanford 2001), with no resuspension induced (Fig. 1e). Both the NR and R tanks have been described in more detail by Sanford et al. (2009). 
Experimental setup. We collected muddy sediment from Baltimore Harbor $\left(39^{\circ} 11^{\prime} 29^{\prime \prime} \mathrm{N}, 7^{\circ} 31^{\prime} 10.5^{\prime \prime} \mathrm{W}\right)$ using a Van Veen grab with the sediment placed into buckets. Sediment at the collection site had a grain size of $0 \%$ gravel, $3.27 \%$ sand, $38.7 \%$ silt, and $58.03 \%$ clay, measured as percent dry weight (Baker et al. 1997); the percent nitrogen and carbon content were 0.33 and $4.57 \%$, respectively (Baker et al. 1997). The sediment was moved to an outdoor fiberglass tank and covered with black plastic. Sediment was defaunated and prepared using the techniques for large-scale sediment preparation developed by Porter et al. (2006) and briefly described below.

Before the start of the experiment, we kept the sediment anaerobic for $\geq 4 \mathrm{~d}$ to remove macrofauna. Then we discarded the top $10 \mathrm{~cm}$ of the sediment layer and added the underlying sediment evenly to the 6 mesocosms to form a $10 \mathrm{~cm}$ bottom sediment layer. The muddy sediment in the mesocosms was mixed thoroughly, then carefully smoothed and leveled using a
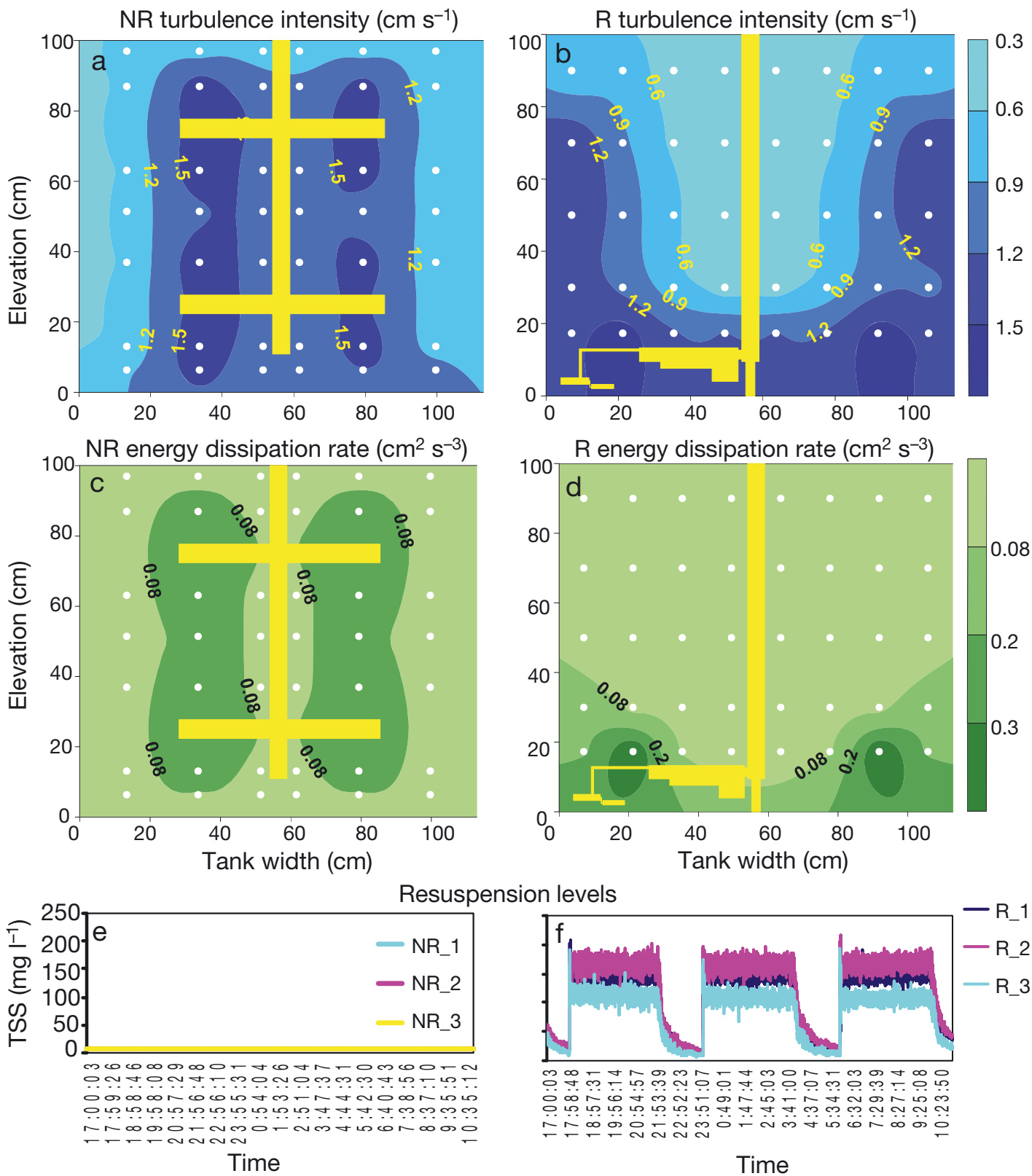

Fig. 1. Turbulence intensity in the (a) non-resuspension (NR) tanks and (b) resuspension (R) tanks, with paddles in the tanks indicated in yellow. Energy dissipation rate in the (c) NR tanks and (d) R tanks. The circles indicate measurement locations (a to d). Concentrations of total suspended solids (TSS) generated by tidal cycles ( $4 \mathrm{~h}$ mixing-on, $2 \mathrm{~h}$ mixing-off) in the (e) NR tanks and (f) $\mathrm{R}$ tanks, $\mathrm{n}=3$ tanks each 
polyvinylchloride (PVC) bar that was spun around the central axis of each tank. The mesocosms were held in the dark and filled slowly to about $20 \mathrm{~cm}$ water depth with $0.5 \mu \mathrm{m}$ (absolute) filtered water from the Patuxent estuary (Solomons, Maryland). A $\sim 10 \mathrm{~cm}$ water layer was replaced daily for a 2 wk period to flush out solutes. Experiments by Porter et al. (2006) found that homogenized sediments have high initial ammonium effluxes, and an equilibration period of about 2 wk is needed for sediments to return to typical porewater gradients and effluxes. We also added defaunated mixed sediment to three $13 \mathrm{~cm}$ diameter benthic chambers that were placed in the dark with a slow through flow of $0.5 \mu \mathrm{m}$ filtered Patuxent water. The benthic chamber sediments were used as proxies for the initial condition of the mesocosm sediments to avoid having to core the mesocosm sediments at the beginning of the experiment.

To prevent overheating of the tank water from high outdoors summer temperatures (up to $38^{\circ} \mathrm{C}$ ), the side walls of each tank were wrapped with a layer of aluminum foil-covered bubble wrap insulation (Shelter Institute). In addition, we added 3 layers of window mesh over the superstructure, ca. $1.5 \mathrm{~m}$ above the tanks. We made sure that incident light was not limiting by regularly measuring light levels at the water surface in the tanks using a LI-192 underwater quantum sensor (LI-COR Biosciences) light meter, set to the 'air' reading and attached to a Model LI-250 light meter readout. Any light limitation within the tanks, thus, was due to resuspension, with associated effects on water turbidity and light penetration within the tanks. In previous experiments (Porter et al. 2004a), we had found that light levels of about $160 \mu \mathrm{mol}$ photons $\mathrm{m}^{-2} \mathrm{~s}^{-1}$ are required at the water surface to prevent light limitation. We measured light levels of about $265 \mu \mathrm{mol}$ photons $\mathrm{m}^{-2} \mathrm{~s}^{-1}$ at the water surface of the NR and $\mathrm{R}$ tanks in this experiment.

At the start of the mesocosm experiment, 2 wk after sediments had been added to the NR and R tanks, unfiltered water of ca. $12 \mathrm{~g} \mathrm{~kg}^{-1}$ salinity with a plankton community from the Patuxent River, a tributary of Chesapeake Bay, excluding only megazooplankton $\geq 3 \mathrm{~cm}$, was slowly added to the mesocosms via plates held at the water surface, so as not to cause any sediment resuspension; the tanks were thus filled to $1 \mathrm{~m}$ water depth. Mixing was then turned on, and tidal cycles were mimicked for $4 \mathrm{~h}$ on and $2 \mathrm{~h}$ off cycles. Mixing in all tanks was cycled on/off at the same time. Over the first $1.5 \mathrm{~d}$ of the experiment, the mixing setting was adjusted twice in the R and NR tanks, where the settings between the tanks were carefully kept similar in turbulence intensity, after the initial setting in the $\mathrm{R}$ tanks did not cause the desired resuspension level of about $100 \mathrm{mg} \mathrm{l}^{-1}$. This target resuspension level, though high relative to levels in Baltimore Harbor, is well within the range of tidal resuspension observed in other muddy estuaries. It was chosen to maximize the likelihood of observable differences between the $\mathrm{R}$ and $\mathrm{NR}$ tanks within a reasonable range, not to mimic the precise environment from which the sediments were obtained. Turbulence intensity and energy dissipation rates were kept the same in all tanks. Mixing in the R tanks was accidentally left off overnight between Days 20 and 21, but the experiment was continued through Day 29, with little apparent effect of the 2 missed R cycles. On Day 28 the paddle in Tank 2 fell off, and seston data from the last day of Tank 2 were not included in the analyses.

Ten percent of the water in each tank was exchanged daily at the end of the mid-day mixing-off phase and replaced with $0.5 \mu \mathrm{m}$ absolute filtered Patuxent estuary water. We cleaned tank walls of wall periphyton biweekly or more often as needed to minimize wall growth (Chen et al. 1997), but left the scrapings in the tanks. On Day 2 of the experiment, we added a nutrient spike with ammonium $(25 \mathrm{ml}$ of a solution of $53.5 \mathrm{~g} \mathrm{l}^{-1} \mathrm{NH}_{4} \mathrm{Cl}$ ) and soluble reactive phosphorus (25 ml of a solution of $8.51 \mathrm{~g} \mathrm{l}^{-1} \mathrm{KH}_{2} \mathrm{PO}_{4}$ ), in Redfield proportions, to each $1000 \mathrm{l}$ tank to stimulate phytoplankton growth as had been done in other mesocosm experiments (Petersen et al. 1998, Porter et al. 2004b). Nutrient samples were taken from each tank very shortly after the spike had been added, and the nutrient concentrations were immediately analyzed to confirm the spike was successful. Watercolumn ammonium concentrations in the tanks were $25 \mu \mathrm{mol} \mathrm{l}^{-1}$, and the soluble reactive phosphorus concentrations were $1 \mu \mathrm{mol} \mathrm{l}^{-1}$ on the day after the spike was added. Silica was abundant with $45 \mu \mathrm{mol} \mathrm{l}^{-1}$ at the start of the experiment, and no silica additions were made. The ecosystem experiment was performed at the Chesapeake Biological Laboratory, University of Maryland Center for Environmental Science in Solomons, Maryland.

Sampling regime and variables sampled. Turbidity was monitored continuously at $1 \mathrm{~s}$ intervals in each tank with optical backscatter (OBS-3, D\&A Instrument Company) turbidity sensors located at mid-depth. The OBS sensor output was calibrated to total suspended solids (TSS) for samples taken at the same depth over the course of the experiment. TSS samples were analyzed by filtration as described below. The resulting calibration was given by a TSS concentration of 50.512 $\times$ OBS_Volts $+1.760\left(\mathrm{r}^{2}=0.974\right)$. In post-processing, the OBS data were averaged over $66 \mathrm{~s}$ intervals. In addition, we measured dissolved oxygen concentrations daily at mid-depth in each tank using a YSI 6600 sonde during afternoon mixing-on phases. Water temperature in each tank was measured at 10 min inter- 
vals during the experiment using Campbell T107 temperature probes connected to a Campbell CR10 data logger (Campbell Scientific).

We used a LI-192 underwater quantum sensor (LICOR Biosciences) light meter to measure total downwelling photosynthetically active radiation (PAR, in the 400 to $700 \mathrm{~nm}$ waveband) at several depths. The data were used to determine light attenuation coefficients and to calculate irradiance levels at the sediment surface. In addition, mean geometric irradiance in the water column was calculated as $\exp \left\{0.5 \times\left[\ln \left(E_{0}\right)+\right.\right.$ $\left.\left.\ln \left(E_{\text {Sed }}\right)\right]\right\}$, where $E_{0}$ and $E_{\text {Sed }}$ are irradiances at the surface of the water column and the sediment-water interface, respectively. The values obtained for mean geometric irradiance were similar to irradiance values measured at $50 \mathrm{~cm}$ depth. For the first $5 \mathrm{~d}$, irradiance profiles were determined at the surface and at $25 \mathrm{~cm}$ and $50 \mathrm{~cm}$ below the surface. During the remainder of the experiment, light was also measured 10,50, and $65 \mathrm{~cm}$ from the surface. The light meter covers the light spectrum from 400 to $700 \mathrm{~nm}$ (Kirk 1994). Most measurements were done during the afternoon. In addition, we measured light penetration using a PVC cap painted black and white, similar to a Secchi disk, mounted on a PVC rod and lowered into the water column until it disappeared from view.

Every $2 \mathrm{~d}$ over the $4 \mathrm{wk}$ experiment, during the morning mixing-on phase, 1 discrete water sample per tank was carefully siphoned from mid-depth of each tank into sampling bottles to be filtered for various analyses. For TSS analyses, known volumes of water were filtered in triplicate through ashed, pre-weighed $47 \mathrm{~mm}$ diameter glass-fiber filters $(0.7 \mu \mathrm{m}$ nominal pore size $)$ and rinsed with isotonic ammonium formate to remove salts (Berg \& Newell 1986). In addition, we obtained particulate inorganic matter (PIM) and particulate organic matter (POM) concentrations from these samples. Known volumes of water were filtered through $25 \mathrm{~mm}$ Whatman GFF filters for analyses of particulate carbon $(\mathrm{PC})$, particulate nitrogen (PN), and particulate phosphorus (PP). Water was filtered through $47 \mathrm{~mm}$ Nucleopore filters $(0.45 \mu \mathrm{m}$ nominal pore size) to determine particulate silica concentrations. We also filtered known volumes of water through $47 \mathrm{~mm}$ Whatman GFF filters for analyses of chlorophyll a (chl a) and phaeophytin. Some of this water was also filtered through Whatman GFF filters, and the solute was frozen in individual vials for later analysis of dissolved nutrients such as ammonium $\left(\mathrm{NH}_{4}{ }^{+}\right)$, nitrate + nitrite $\left(\mathrm{NO}_{3}{ }^{-}+\mathrm{NO}_{2}{ }^{-}\right)$, dissolved phosphate $\left(\mathrm{PO}_{4}{ }^{3-}\right)$, dissolved silica ( $\left.\mathrm{Si}\right)$, total dissolved nitrogen (TDN) concentrations, and total dissolved phosphorus (TDP) concentrations. The 10\% daily exchange water was also sampled for dissolved nutrients, and the fill water was sampled once for particulates to confirm low abundance.
At the start of the experiment and then once weekly, water was filtered through $25 \mathrm{~mm}$ Whatman GFF filters $(0.7 \mu \mathrm{m}$ nominal pore size), which were folded and stored in aluminum foil in a $-70^{\circ} \mathrm{C}$ freezer until phytoplankton pigment analyses with high performance liquid chromatography (HPLC) (Van Heukelem \& Thomas 2001) could be performed.

Following Jeffrey \& Vesk (1997), Marshall (1994) and Marshall et al. (2005), some pigments characteristic of phytoplankton in the Chesapeake Bay area, our source water, were defined: alloxanthin (Cryptophyceae), fucoxanthin (Chrysophyceae and Bacillariophyceae), lutein (Chlorophyceae and Prasinophyceae), peridinin (Dinophyceae), and zeaxanthin (cyanobacteria). We also found the pigment 19'-butanoyloxyfucoxanthin (but-fuco), which is a marker pigment for brown tide organisms Aureococcus anophagefferens (Trice et al. 2004) when 19'-hexanoyloxyfucoxanthin is absent (compare pigments of Prymnesiophyceae and Chrysophyceae in Table 2.3 , p. 74 to 75 , in Jeffrey \& Vesk 1997) and when gyroxanthin diester is absent (Table 50, p. 88 to 89, in Van Heukelem \& Thomas 2005). Gyroxanthin diester was absent throughout the experiment, and 19'-hexanoyloxyfucoxanthin was absent, except on Day 5 of the experiment and in $1 \mathrm{R}$ tank on Day 18 of the experiment. Thus, as in the study by Trice et al. (2004), but-fuco in the present study was used to indicate the presence of the chrysophyte Aureococcus anophagefferens. Moreover, Marshall et al. (2005) reported A. anophagefferens in Chesapeake Bay water, which was our source water. We report the pigment to chl a ratio for the above pigments since chl a abundance varied between the R and NR tanks.

At random, duplicate subsamples were filtered for quality control during each sampling. More frequent samples of TSS were also collected during 3 mixing-off periods to examine changes in the particulate properties over time during settling.

Mesozooplankton samples were collected twice a week during mixing-off phases by pumping $40 \mathrm{ltank}^{-1}$ at a rate of $22.21 \mathrm{~min}^{-1}$ with a diaphragm pump through a $63 \mu \mathrm{m}$ Nitex screen. The mesh content was washed into bottles, mesozooplankton was preserved with buffered formaldehyde, and the dominant taxa and age groups were later determined on a dissecting microscope using direct counts.

Sediment chl $a$, phaeophytin, PC, and PN concentrations in the surface sediment, as well as the sediment water content were measured in the tanks mid-way into the experiment (on Day 11) and at the end of the experiment (Day 29). At the start of the ecosystem experiment (Day 0), these variables were measured in the benthic chambers set up in parallel to the mesocosm experiment as described above, to represent the sediment conditions at the start of the experiment. To 
sample the tanks for sediment chl $a$, phaeophytin, PC, $\mathrm{PN}$, and sediment water content, we used $2.5 \mathrm{~cm}$ diameter cut-off syringes with a 1-way valve (BE130-23BB, Instrumentation Industries) as coring devices. In the tanks, the sediment corer was affixed to a pole for remote coring. Triplicate sediment samples were collected from 3 tank quadrants during the mixing-on phase. Mixing was only briefly turned off while sampling. For the initial benthic chamber sediment samples, only the surface section of 0 to $0.5 \mathrm{~cm}$ was collected. In the mesocosm tanks, we sampled both the 0 to 0.5 and 0.5 to $1 \mathrm{~cm}$ sediment sections, but combined them for data analysis. To compensate statistically for the missing 0.5 to $1 \mathrm{~cm}$ section of the initial benthic chamber cores, $35 \%$ of the 0 to $0.5 \mathrm{~cm}$ section chl a was added based on the average ratio in all cores for which data in both sections were available. Sediment chl a and phaeophytin samples were frozen at $-70^{\circ} \mathrm{C}$ pending analysis with HPLC (Van Heukelem \& Thomas 2001).

To determine the abundance of any macroinfauna that may have settled or grown up over the $4 \mathrm{wk}$ period of the experiment, we took $13.3 \mathrm{~cm}$ diameter sediment cores from the tanks at the end of the experiment. We washed the contents through a $0.5 \mathrm{~mm}$ diameter mesh, counted the animals, and estimated the macrofaunal abundance per square meter. No macroinfauna were found in the initial benthic chamber cores.

Zooplankton. Dominant taxa in the mesozooplankton and age groups were determined on a dissecting microscope using direct counts. The dominant taxa were copepod nauplii, Acartia spp. adults, polychaete larvae, and copepodites. To estimate the dry weights of the individuals of the different taxa, the number of individuals was multiplied by the respective weight characteristic for individuals of these taxa provided in Table 2 by White \& Roman (1992; $W, \mu \mathrm{g}$ ind. ${ }^{-1}$ ). Thus, the number of adult $A$. tonsa for each sampling day was multiplied by 8 , the number of polychaete larvae by 1.3 , the number of copepodites by 2.7 , and the number of nauplii by 0.31 .

We converted zooplankton weight to carbon $\left(\mu \mathrm{g} \mathrm{l}^{-1}\right)$ for each taxon and combined the taxa for an estimate of combined mesozooplankton biomass to compare the relative biomass of phytoplankton and mesozooplankton abundance (in a common carbon unit) following White \& Roman (1992; Table 1: 'Carbon [ $\mu \mathrm{g} \mathrm{C}$ ind.$\left.^{-1}\right]=$ $0.32 W^{\prime}$ ). Phytoplankton carbon estimation is described below. Simple correlation analysis and linear regression analysis were performed using SAS (SAS Institute). In addition, we estimated the nitrogen content of the zooplankton community for an overall nitrogen budget as described with the nitrogen budget below.

Sediment flux experiments and porewater release estimates. At the end of the mesocosm experiment, we removed 3 sediment cores per tank using $13.3 \mathrm{~cm}$ diameter clear acrylic core tubes. Unfortunately, the cores from $1 \mathrm{R}$ tank were not usable. The cores from the remaining 5 tanks were capped off and arranged around turntables with magnets around their outer edges to drive stir bars attached to the core caps. Standard sediment flux techniques were used. Briefly, we added filtered Patuxent River water to the benthic chambers before sealing them air-tight, added stirring (without resuspension), and incubated the cores first in the dark and then in the light to obtain sediment oxygen, ammonium, nitrate + nitrite, and dissolved inorganic nitrogen $\left(\mathrm{DIN}=\mathrm{NH}_{4}{ }^{+}+\mathrm{NO}_{3}{ }^{-}+\mathrm{NO}_{2}{ }^{-}\right.$) fluxes in the dark and in the light. Control (blank) cores without sediment were run at the same time. In addition, we determined the daily flux rates (flux rate in the light + flux rate in the dark). Nutrient samples were filtered through a $0.45 \mu \mathrm{m}$ filter, frozen at $-20^{\circ} \mathrm{C}$ (Parsons et al. 1984) and analyzed following techniques detailed by Keefe et al. (2004). Sediments at the start of an experiment were taken, as described above, from the flowthrough water bath and incubated only in the dark to determine fluxes. To estimate the contribution of porewater resuspension to the $\mathrm{N}$ budget, we estimated porewater release from the $2 \mathrm{~mm}$ layer of sediment that was resuspended regularly during the mixing-on cycle.

Microcosm erosion experiments. At the end of the mesocosm experiment, we collected duplicate sediment cores from $2 \mathrm{R}$ and 2 NR tanks for erosion tests, each in a $10 \mathrm{~cm}$ diameter 'microcosm' (Gust \& Müller 1997, Thomsen \& Gust 2000, Dickhudt et al. 2009). The bottom shear stress in these devices is approximately homogeneous across the sediment surface, at settings from 0 to $0.35 \mathrm{~Pa}$. For each of the 4 erosion cores, we increased bottom shear stress in steps of $0.01,0.05,0.1$, $0.15,0.2,0.25,0.3$, and $0.35 \mathrm{~Pa}$. Each erosion step was run for a $10 \mathrm{~min}$ period. Samples for each step were analyzed for TSS, sediment chl $a$, and phaeophytin concentrations. For Core 2 of the NR systems, water was lost from 2 sample bottles and thus the sample was lost. For Core 2 of the R systems, chl a data were lost for shear stress steps 0.3 and $0.35 \mathrm{~Pa}$. Sediment depth $\left(z_{\text {, }}\right.$ in $\mathrm{mm}$ ) was estimated from mass eroded per unit area $\left(m\right.$, in $\left.\mathrm{kg} \mathrm{m}^{-2}\right)$ assuming $95 \%$ sediment porosity $(\phi)$ and a sediment density $\left(\rho_{s}\right)$ of $2500 \mathrm{~kg} \mathrm{~m}^{-3}$ as follows:

$$
z=\frac{m}{(1-\phi) \rho_{s}}=\frac{m}{0.125}
$$

Analytical methods. After drying seston filters for $24 \mathrm{~h}$ to constant weight at $60^{\circ} \mathrm{C}$, they were re-weighed on a Mettler AE 240 microbalance to determine TSS mass. Filters were then ashed at $450^{\circ} \mathrm{C}$ for $4 \mathrm{~h}$ and re-weighed to determine PIM; POM was determined by the difference between TSS and PIM (Berg \& Newell 1986). 
Chl a concentrations were measured to provide estimates of phytoplankton biomass using fluorometric techniques without acidification (Welschmeyer 1994) after extraction with $90 \%$ acetone. Phaeophytin was measured using HPLC (Van Heukelem \& Thomas 2001).

$\mathrm{PC}$ and $\mathrm{PN}$ samples were analyzed on an Exeter Analytical (CHN) analyzer using Environmental Protection Agency Method 440.0 (Zimmermann et al. 1997). POC was determined using $\mathrm{POC}=\mathrm{POM} \times 0.5$ (Geider 1987 and references therein). The POC to chl a ratio was determined following Steele \& Baird (1965) and Chang et al. (2003), by regression analysis in SAS. In addition, water samples were analyzed for PP following techniques described in Keefe et al. (2004). Ammonium, nitrite + nitrate, and phosphate were analyzed following the Technicon Industrial Methods Nos. 804-86T, 15871W/, and 155-71W/Tentative, respectively, and TDN and TDP were analyzed using methods described by Keefe et al. (2004). Dissolved organic nitrogen (DON) was calculated by the difference between TDN and DIN. DOP was calculated by the difference between TDP and $\mathrm{PO}_{4}{ }^{3-}$. Dissolved silica was analyzed using a Technicon TrAAcs-800 nutrient analyzer with oxalic acid added to minimize interference from phosphates, and particulate silica was analyzed as described by Keefe et al. (2004). For all variables, for quality control, each sixth sample was analyzed in duplicate. Nutrients and water-column chl a were analyzed by the Analytical Services Laboratory of the Chesapeake Biological Laboratory, University of Maryland Center for Environmental Science (standard operating procedures available at: http://archive. chesapeakebay.net/pubs/quality_assurance/CBL_NASL _SOP_Feb_2004.pdf).

Sediment chl a and phaeophytin samples were analyzed with HPLC (Van Heukelem \& Thomas 2001). HPLC was used to prevent degradation products such as chlorophyllides and phaeophorbides from interfering with fluorescence measurements (MacIntyre et al. 1996) and affecting chl a readings. We followed extraction procedures outlined in the dissertation by Porter (1999), done in collaboration with Laurie Van Heukelem, that extract about $97 \%$ of the sediment chl a from samples that contain a range of sediment chl a concentrations; however, pigment extraction procedures have been described in much greater detail in Wright et al. (1997). Extracts from replicate tank samples were pooled and analyzed for chl $a$ and phaeophytin.

We also estimated nitrogen budgets in the R and NR tanks. Water-column chl a was converted to nitrogen equivalents (phytoplankton biomass nitrogen, $\mu \mathrm{mol} \mathrm{N}$ $\operatorname{tank}^{-1}$ ) using the ratio of POC to chl a of 51.68 (regression analysis; Steele \& Baird 1965, Chang et al. 2003) determined from the NR tank data and assuming that the POC represents phytoplankton carbon. We also used the measured carbon to nitrogen ratio of 5.138 for the NR tank phytoplankton during the experiment. Nitrate + nitrate concentrations were closely coupled with changes in chl a biomass. The POC to chl a ratio of 51.68 in the NR tanks was comparable to the $\mathrm{C}$ to $\mathrm{chl}$ a ratio of 50 that has widely been used in modeling studies in a variety of environments (e.g. Harding et al. 2002). The POC to chl a relationship for the phytoplankton in the $\mathrm{R}$ tanks was not meaningful given the large amount of non-living matter (resuspended sediment C) in the POM. Thus, the POC to chl a ratio of the NR tanks was also applied to the R tanks. Sediment chl $a$, indicative of microphytobenthos abundance, was converted to nitrogen equivalents ( $\mu \mathrm{mol} \mathrm{N}_{\operatorname{tank}}{ }^{-1}$ ) following the same procedures as for water-column chl $a$, after converting $\mathrm{mg} \mathrm{chl} a \mathrm{~m}^{-2}$ to $\mu \mathrm{g}$ of $\mathrm{chl} a \mathrm{~m}^{-2}$. To estimate the $\mathrm{N}$ content of the zooplankton community, we determined the dry weights of the individuals of the different taxa as described above, then the numbers were scaled up to total dry weight in the tanks using measured abundances. The dominant taxa were copepod nauplii, Acartia spp. adults, polychaete larvae, and copepodites. The nitrogen content of the mesozooplankton stock in the tanks was determined as $7.5 \%$ of the mesozooplankton dry weight (5 to $10 \%$ of mesozooplankton dry weight is nitrogen; Parsons et al. 1984). Water-column concentrations of TDN were scaled up to the whole tank. For accuracy, we also estimated the contribution of porewater nutrient flux to the water-column $\mathrm{N}$ budget. Macroinfauna was found only in the NR tanks, and their lengths were not measured, but macroinfauna nitrogen is assumed to be a small fraction of the total nitrogen.

Statistical analyses. Chl $a$, TSS, phaeophytin, PN, PP, and $\mathrm{PC}$, and the dissolved inorganic and organic nutrients were each averaged from Day 6 to the end of the experiment for each tank (ca. 8 measurements over a $3.5 \mathrm{wk}$ period). Data from the first $5 \mathrm{~d}$ of the experiment were not included in the averages, to avoid the immediate effects of the initial nutrient spike, such that the averaged data for the most part represent the response to the spike rather than the spike itself. Mesozooplankton abundance was averaged for each tank over the entire experiment. Only data from the mixing-on phases were included in statistical comparisons. Statistical $t$-tests were used for water-column chl $a_{1}$, phaeophytin, zooplankton abundance, PN, PC, the dissolved nutrient data, the dissolved oxygen data, and the phytoplankton accessory pigment data. Split-plot analyses were used for the results of the sediment flux experiments. Splitplot analyses in time were used for sediment chl a over the duration of the experiment. To determine the relationship between the mesozooplankton community and phytoplankton, correlation analysis and linear regression analyses of mesozooplankton biomass and phytoplankton biomass were used. Statistical analyses were 
performed using SAS (SAS Institute), and the $t$-tests using the Microsoft Excel Analysis ToolPak (Microsoft Corp.). Significances of all analyses were defined at the $\mathrm{p} \leq 0.05$ level.

\section{RESULTS}

\section{Water-column processes}

Over the 4 wk long experiment, TSS levels were obviously enhanced (100 to $220 \mathrm{mg} \mathrm{l}^{-1}$ ) in the R tanks compared to the NR tanks (6 to $18 \mathrm{mg} \mathrm{l}^{-1}$ ) (Fig. 2a, Table 1a), as were PIM and POM concentrations
(Table 1a). After the adjustments to the mixing settings in the R and NR tanks for the first $1.5 \mathrm{~d}$ (see above), the final maximum shear stress levels in the $\mathrm{R}$ tanks were from 0.35 to $0.4 \mathrm{~Pa}$, and seston concentrations were $170 \mathrm{mg} \mathrm{l}^{-1}$. These decreased to about $120 \mathrm{mg} \mathrm{l}^{-1}$ towards the middle of the experiment, before increasing again towards the end of the experiment (Fig. 2a). PC, PN, and PP concentrations were linearly related to TSS concentrations (Table 2) and thus were enhanced in the R tanks (Table 1c). Particulate matter quality was, however, significantly higher in the NR tanks as demonstrated by: (1) higher POM:PIM ratios (Table 1a), (2) higher chl a: phaeophytin ratios (Fig. 2d, Table 2b), and (3) a lower $\mathrm{PC}: \mathrm{PN}$ ratio, typical of that for phytoplankton (Table 1c).
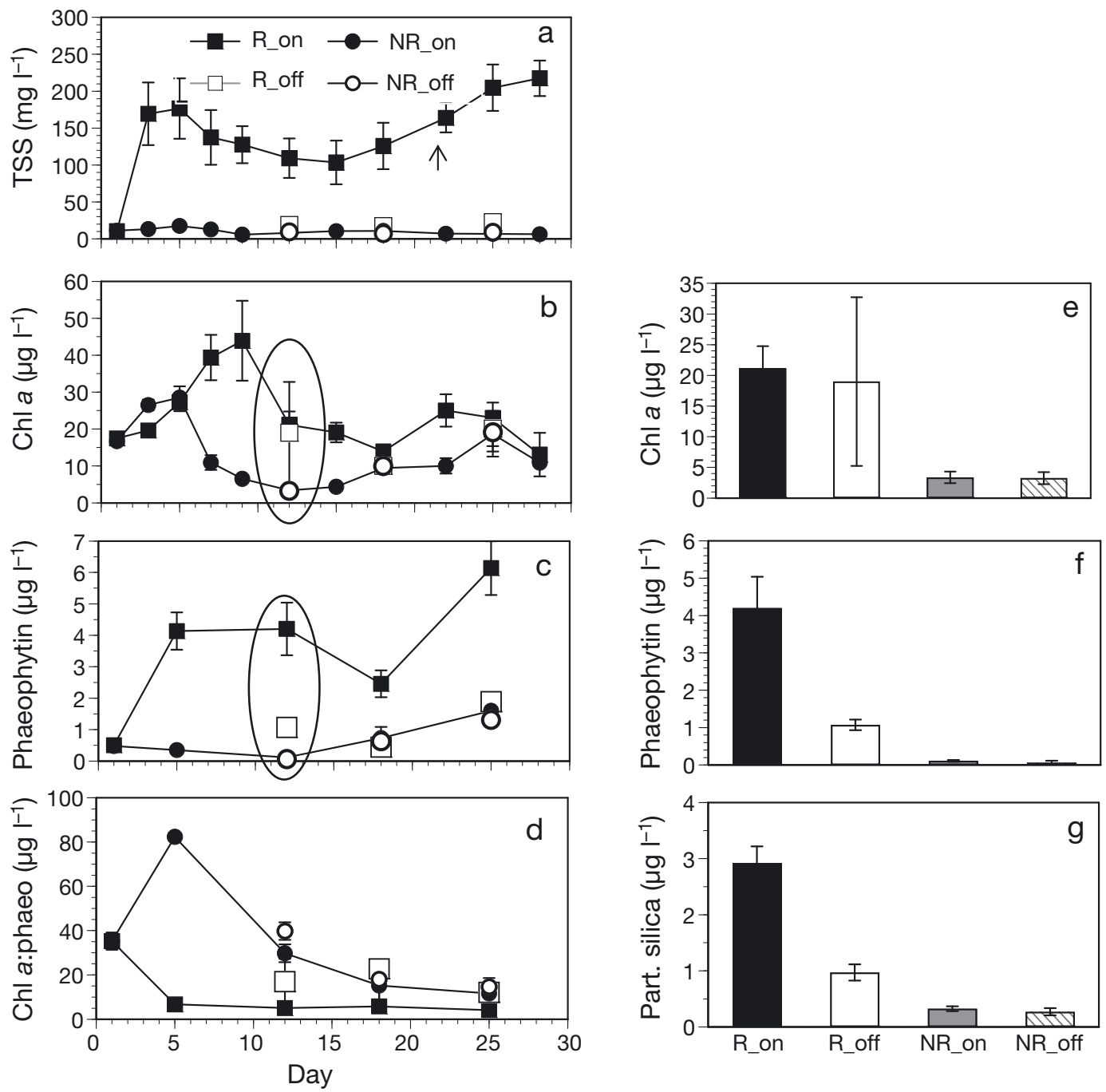

Fig. 2. Results over time in the non-resuspension (NR) and resuspension (R) tanks during the mixing-on and mixing-off phases. Concentrations of (a) total suspended solids (TSS) (samples on Day 1 were taken near the time that mixing was started), (b) chlorophyll a (chl $a_{\text {; }}$ technique according to Welschmeyer 1994), (c) phaeophytin (phaeo; HPLC technique), and (d) chl a:phaeo

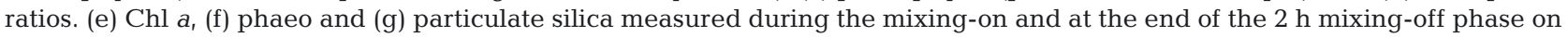
Day 12 (circled in Panels b and c). Arrow in (a) indicates when the paddles were accidentally shut off for two mixing-on cycles in the R tanks. $n=3$ tanks for each system and mixing phase, reported are the averages \pm SD. For statistical results see Table $1 \mathrm{a}, \mathrm{b}$ 
Water-column chl a (20 to $50 \mathrm{\mu g} \mathrm{l}^{-1}$ ) and phaeophytin (4 to $6 \mu \mathrm{g} \mathrm{l}^{-1}$ ) levels were significantly higher in the $\mathrm{R}$ than in the NR tanks (Fig. 2b,c, Table 1b). Very little benthic chl $a$ was resuspended in the R tanks (Fig. 2e), but phaeophytin concentrations differed significantly between the mixing-on and the mixing-off phases in the $\mathrm{R}$ tanks, as degraded material was resuspended and deposited (Fig. 2c,f). The ratio of chl a to phaeophytin was 2 to 16 times higher in the NR than in the R tanks (Fig. 2d). The overall abundance of degraded material was low in the NR tanks, and there was no significant difference in degraded material between the mixing-on and mixing-off phases (Fig. 2c,f).

The phytoplankton community structure was also affected by resuspension (Fig. 3). Peridinin (indicative of Dinophyceae; Fig. 3a) decreased rapidly in the $\mathrm{R}$ and NR tanks after the start of the experiment and the nutrient spike. Lutein concentrations (indicative of Chlorophyceae and Prasinophyceae; Fig. 3b) were higher in the R than in the NR tanks, whereas zeaxanthin (cyanobacteria; Fig. 3d) concentrations were
Table 2. Particulate carbon $(\mathrm{PC})$, particulate nitrogen $(\mathrm{PN})$, particulate phosphorus (PP) concentrations in the resuspension and the non-resuspension systems from Day 6 to the end of the experiment, and their regression relationship with total suspended solid (TSS) concentrations; $\mathrm{n}=85$

\begin{tabular}{|lc|}
\hline Regression & $\mathrm{R}^{2}$ \\
\hline $\mathrm{PC}\left(\mathrm{mg} \mathrm{l}^{-1}\right)=0.04189 \times \mathrm{TSS}\left(\mathrm{mg} \mathrm{l}^{-1}\right)+0.7156$ & 0.97 \\
$\mathrm{PN}\left(\mathrm{mg} \mathrm{l}^{-1}\right)=0.00397 \times \mathrm{TSS}\left(\mathrm{mg} \mathrm{l}^{-1}\right)+0.172$ & 0.93 \\
$\mathrm{PP}\left(\mathrm{mg} \mathrm{l}^{-1}\right)=0.00256 \times \mathrm{TSS}\left(\mathrm{mg} \mathrm{l}^{-1}\right)+0.004856$ & 0.99 \\
\hline
\end{tabular}

higher in the NR than in the R tanks. Fucoxanthin (Chrysophyceae and Bacillariophyceae; Fig. 3c) and alloxanthin (Cryptophyceae; Fig. 3e) concentrations were higher in the R than in the NR tanks. But-fuco concentrations, the pigment marker for Aureococcus anophagefferens (brown tide) (Trice et al. 2004), were also higher in the $\mathrm{R}$ than in the NR tanks (Fig. 3f). These brown tide microorganisms developed to a small bloom in the R systems with ca. 5300 cells ml ${ }^{-1}$ by the end of the experiment, based on the pigment to cell
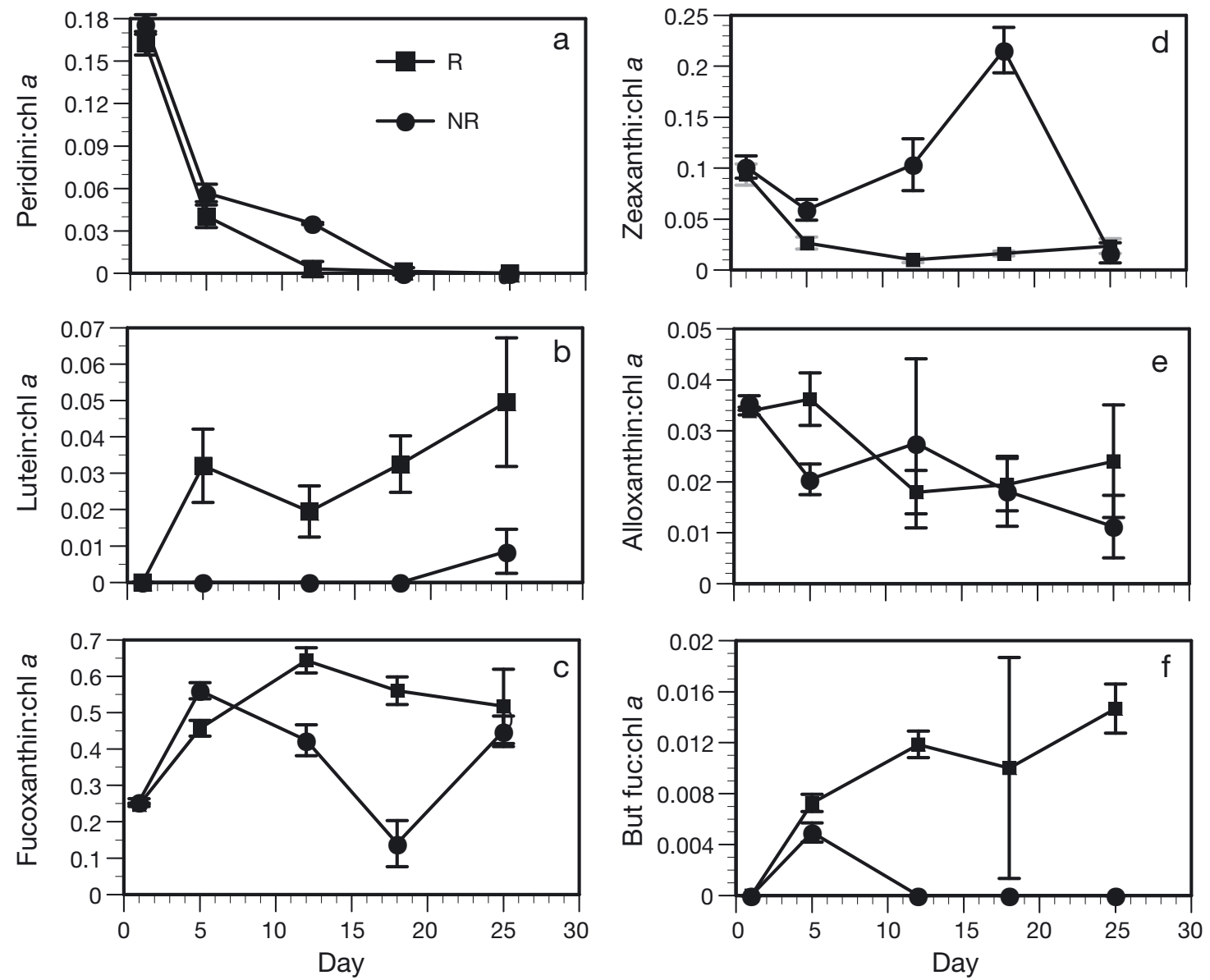

Fig. 3. (a to f) Ratios of phytoplankton accessory pigments to chlorophyll a (chl a; Welschmeyer 1994). But fuco: 19'-butanoyloxyfucoxanthin, marker pigment for the brown tide algae Aureococcus anophagefferens (Trice et al. 2004) if gyroxanthin diester and 19 ' hexanoyloxyfucoxanthin are absent (see 'Results'); $\mathrm{n}=3$ tanks for each system $\pm \mathrm{SD}$ 
count conversions of Trice et al. (2004). The ratio of but-fuco to chl a steadily increased throughout the experiment until the last measurement on Day 25; however, 19'-hexanoyloxyfucoxanthin was also present in all tanks on Day 5 and in 1 tank on Day 18. Gyroxanthin diester was absent in this experiment as checked by Crystal Thomas, Horn Point Laboratory.

Nitrite + nitrate concentrations were significantly enhanced in the $\mathrm{R}$ tanks compared to the NR tanks (Fig. 4a, Table 1d) and so were the overall DIN concentrations, as ammonia levels were similar in both systems (Fig. 4a-C, Table 1d). Increases of nitrate + nitrite (Fig. 4a) were followed by chl a increases (Fig. 2b). As chl a increased, nitrate + nitrite decreased.

DON concentrations were significantly higher in the NR tanks $\left(19.6 \pm 0.5 \mu \mathrm{mol} \mathrm{l}^{-1}\right)$ than in the $\mathrm{R}$ tanks $\left(15.5 \pm 1.2 \mathrm{\mu mol} \mathrm{l}^{-1}\right.$; Fig. 4e, Table 1d), and DON decreased at a faster rate in the $\mathrm{R}$ tanks than in the NR tanks (Fig. 4e). Because of the opposite behaviors of organic and inorganic nitrogen components, watercolumn TDN concentrations were not significantly different between the R and the NR tanks from Day 6 to the end of the experiment (Fig. $4 \mathrm{~d}$, Table 1d). DOP concentrations were significantly higher in the NR tanks $\left(0.375 \pm 0.037 \mu \mathrm{mol} \mathrm{l^{-1 }}\right)$ than in the $\mathrm{R}$ tanks $\left(0.278 \pm 0.019 \mu \mathrm{mol} \mathrm{l}^{-1}\right)$ and did not vary much over the experiment (Fig. 4g). Like ammonium, $\mathrm{PO}_{4}{ }^{3-}$ was taken up rapidly in the $\mathrm{R}$ and $\mathrm{NR}$ tanks after its addition with the nutrient spike (Fig. 4b,f). Dissolved $\mathrm{PO}_{4}{ }^{3-}$ concentrations were higher in the $\mathrm{R}$ than in the NR tanks (Fig. 4f, Table 1d). Dissolved silica concentrations decreased to about $5 \mu \mathrm{mol} \mathrm{l^{-1 }}$ around Day 13 and likely became briefly limiting, but then increased again (Fig. 4i). Dissolved oxygen concentrations were significantly lower in the R tanks than in the NR tanks (Fig. 4h, Table 1d).

Silica limitation was defined as dissolved silica concentrations $<5 \mu \mathrm{mol} \mathrm{l}^{-1}$, nitrogen limitation by DIN concentrations $<2 \mu \mathrm{mol} \mathrm{l}^{-1}$, and phosphorus limitation by phosphate concentrations $<0.1 \mu \mathrm{mol}^{-1}$ (Fisher et al. 1992; T. Fisher, Horn Point Laboratory, University of Maryland Center for Environmental Science, pers. comm.). While silica was generally not limiting in the NR tanks (Fig. 4i), there was likely nitrogen and/or phosphorous limitation in the NR tanks (Fig. 4c, f); however, nutrient addition bioassays such as those used by Fisher et al. (1999) are needed to determine the type of nutrient limitation in the NR tanks. In contrast, the $\mathrm{R}$ tanks were generally not nutrient limited (Fig. 4c,f,i).

Total nitrogen $\left(\mathrm{NH}_{4}{ }^{+}+\mathrm{NO}_{2}{ }^{-}+\mathrm{NO}_{3}{ }^{-}+\mathrm{DON}+\mathrm{PN}\right)$ concentrations were about twice as high in the $\mathrm{R}$ tanks as in the NR tanks, which, given the overall higher $\mathrm{chl} a$ in the R tanks, suggests that resuspended sediment may have been a source of additional nutrients
(Fig. 4j), as discussed further below. Total phosphorus concentrations $\left(\mathrm{PO}_{4}{ }^{3-}+\mathrm{DOP}+\mathrm{PP}\right)$ were about 8- to $10-$ fold higher in the $\mathrm{R}$ tanks than in the NR tanks (Fig. 4k), and the TN:TP ratio was significantly lower in the R tanks than in the NR tanks (Fig. 4l, Table 1e). While DOP concentrations were similar between the systems, most of this increase in TP was due to resuspended PP, which was related linearly to TSS levels (Table 2).

\section{Light penetration and microphytobenthos levels}

Light as measured by a home-made Secchi disk, penetrated about 20 to $30 \mathrm{~cm}$ into the $\mathrm{R}$ tanks during resuspension (Fig. 5b), with no irradiance reaching the bottom (Fig. 5a). During the off phases, light in the R tanks reached 60 to $80 \mathrm{~cm}$ into the water (Fig. 5b), with occasional irradiance levels of up to $10 \mu \mathrm{mol}$ photons $\mathrm{m}^{-2} \mathrm{~s}^{-1}$ at the sediment surface (Fig. 5a). In contrast, in the NR tanks, light always reached the bottom, and the measured bottom irradiance levels ranged between 15 and $35 \mu \mathrm{mol}$ photons $\mathrm{m}^{-2} \mathrm{~s}^{-1}$ (Fig. 5a), and were significantly different from those in the $\mathrm{R}$ tanks (Table 1f). Mean geometric irradiance in the water column was higher in the NR tanks (Table 1f).

Sediment chl a varied significantly between systems and over time. At the start of the experiment, in the benthic chambers, sediment chl a levels were about $10 \mathrm{mg} \mathrm{m}^{-2}$ (Fig. 6). In the middle of the experiment (Day 11, Fig. 6), sediment chl a levels were about 30 and $160 \mathrm{mg} \mathrm{m}^{-2}$ in the R and NR tanks, respectively. At the end of the experiment (Day 29, Fig. 6), sediment chl $a$ levels were about $40 \mathrm{mg} \mathrm{m}^{-2}$ and $110 \mathrm{mg} \mathrm{m}^{-2}$ in the R and NR tanks, respectively. Thus, sediment chl $a$ levels were significantly higher in the NR tanks that received more light at the bottom (Figs. 6 \& 5a) and had low bottom shear stress below erosion thresholds.

\section{Sediment erodibility}

Microcosm erodibility tests were conducted at the end of the mesocosm experiment on 4 sediment cores, 2 from $\mathrm{R}$ tanks and 2 from NR tanks (Fig. 7a). These tests showed little difference in sediment stability between any of the cores. Thus, although the NR and $\mathrm{R}$ tank sediment differed greatly in sediment chl a (presumably microphytobenthos) content, the microphytobenthos did not appear to either stabilize or destabilize the sediment with respect to increasing bottom stress. This may have been due to the presence of polychaetes in the NR sediments (see below). The sediments in the NR tanks also contained more microphytobenthos. Fig. $7 \mathrm{~b}$ illustrates how sediment 

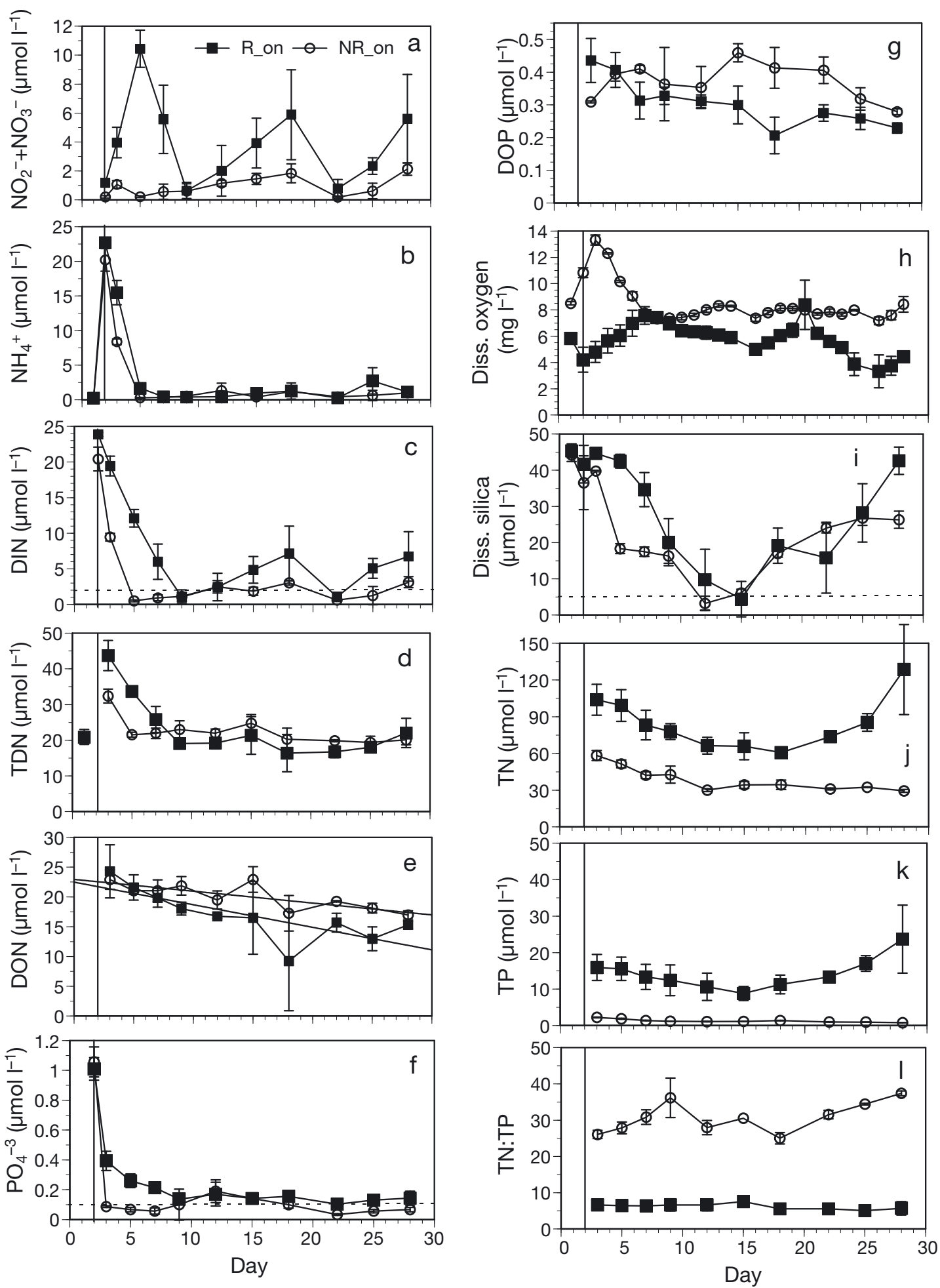

Fig. 4. Dissolved and particulate nutrient and dissolved oxygen concentrations over the experiment; $\mathrm{n}=3$ tanks for each system, reported are means $\pm \mathrm{SD}$ : (a) nitrite + nitrate $\left(\mathrm{NO}_{2}{ }^{-}+\mathrm{NO}_{3}{ }^{-}\right)$, (b) ammonium $\left(\mathrm{NH}_{4}{ }^{+}\right)$, (c) dissolved inorganic nitrogen (DIN), (d) total dissolved nitrogen (TDN), (e) dissolved organic nitrogen (DON), (f) phosphate $\left(\mathrm{PO}_{4}{ }^{3-}\right)$, (g) dissolved organic phosphorus (DOP), (h) dissolved (diss.) oxygen, (i) dissolved silica, (j) total nitrogen (TN), (k) total phosphorus (TP), and (l) TN:TP ratio. Statistical results are presented in Table 1c to e. The vertical lines indicate a nutrient spike of nitrogen and phosphorus added to the water column, and the horizontal dashed lines in Panels c, f, and i indicate thresholds for nutrient limitation for the respective nutrients (see 'Results') 

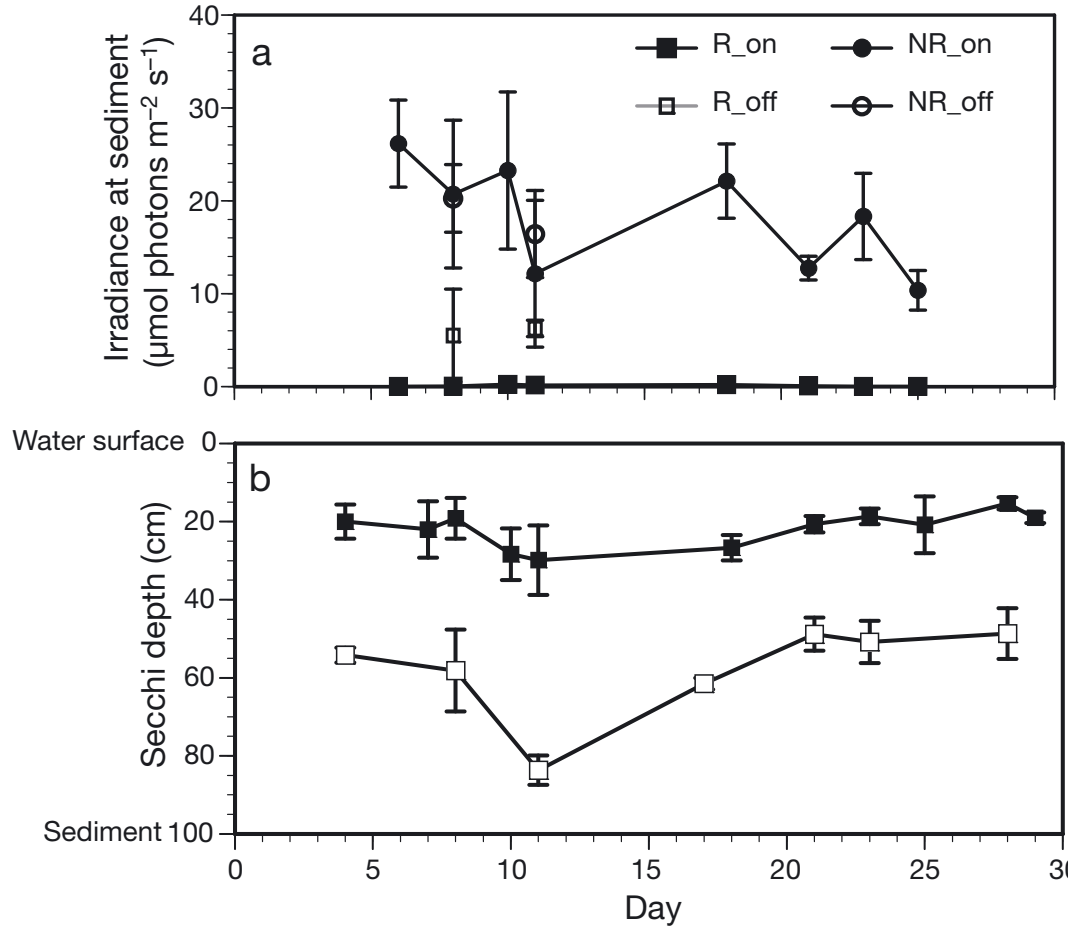

Fig. 5. (a) Irradiance (photosynthetically active radiation, downwelling attenuation; LiCor light meter) calculated at the sediment surface during mixing-on and occasional mixing-off phases showed that light did not reach the bottom during the on phases in the resuspension $(\mathrm{R})$ tanks; $\mathrm{n}=$ 3 for each system, reported are means \pm SD. (b) Secchi depth measured in the R and non-resuspension (NR) tanks during the mixing-on and mixing-off phases over the experiment; for statistical results on irradiance at the sediment surface see Table $1 \mathrm{f}$

chl a was distributed over sediment depth; eroded mass and depth are synonymous for this experimental setup, as shown by the secondary axis in Fig. $7 \mathrm{~b}$. There was a high concentration of chl $a$ in a very thin surficial layer in the $\mathrm{R}$ tank sediments, suggesting deposition of water-column phytoplankton in the latter period of the off phase. In the R tanks, watercolumn chl a concentrations between the mixing-on and mixing-off phases differed by $14 \%$, which was primarily due to phytoplankton that settled and resuspended. In contrast, sediment chl a was found deeper in the sediments and increased in concentration with increasing depth in the NR tanks (Fig. 7b), suggesting the development of a robust microphytobenthos community. The highest stress step in the erodibility tests $(0.35 \mathrm{~Pa})$ eroded about $1 \mathrm{~mm}$ of sediment. The highest instantaneous bottom stress in the $\mathrm{R}$ tanks (about $0.4 \mathrm{~Pa}$ ) resuspended just over $200 \mathrm{mg} \mathrm{l}^{-1}$ by the end of the mesocosm experiments, representing slightly $<2 \mathrm{~mm}$ of erosion using the same conversion from mass to depth. Overall, the mesocosm and erodibility test results are consistent. The 2 lowest stress steps in the erodibility tests $(0.01$ and $0.05 \mathrm{~Pa})$ approximately represent the bottom stress in the NR tanks during the mixing-on phase. Negligible amounts of sediment and chl a were eroded from the NR sediments at these stress levels in the erodibility tests.

\section{Sediment nutrient and dissolved oxygen fluxes and porewater release estimates}

Fluxes were measured using sediment cores taken at the start (only 1 set run) and at the end of the mesocosm experiment (both R and NR sediments). Sediment nutrient and gas fluxes were low at the start of the experiment (Fig. 8a-d). At the end, dissolved oxygen fluxes differed significantly between the dark and light phases in the NR tanks, with oxygen influxes during the dark and oxygen effluxes during the light phase (Fig. 8a). However, there were no significant differences in oxygen fluxes between the dark and light phases for the $\mathrm{R}$ tanks at the end of the experiment (Fig. 8a). Ammonium, nitrite + nitrate, and DIN fluxes were all regenerated from the sediments to the water column (e.g. Fig. 8b-d). There were no significant DIN flux differences between the R and NR tanks or between the dark and light phases. However, DIN effluxes tended to be slightly lower in the light than in the dark (Fig. 8d), as was also seen for the ammonium fluxes (Fig. 8b). The NR systems also showed a trend of slightly enhanced nitrate + nitrite effluxes in the light compared to the fluxes in the dark (Fig. 8c).

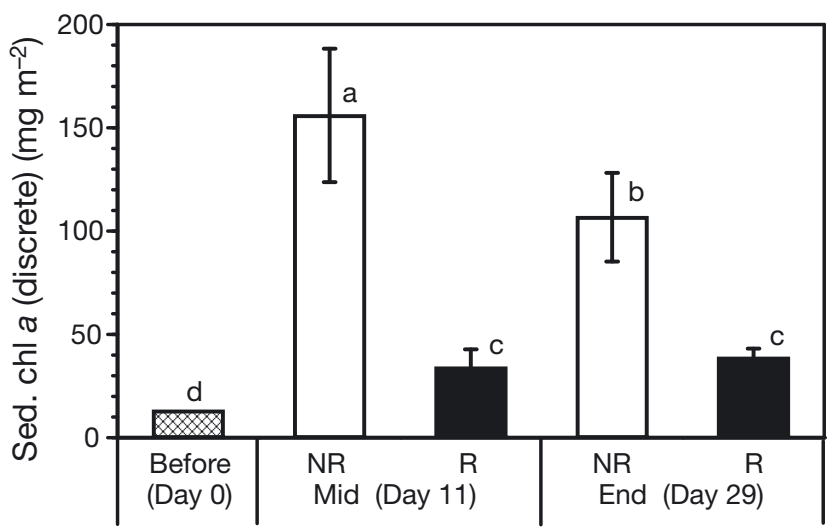

Fig. 6. Sediment chlorophyll a (sed. chl $a_{\text {; }}$ Welshmeyer 1994) levels in the $0-1 \mathrm{~cm}$ depth section of sediment before the experiment, on Day 11 (mid) of the experiment, and at the end of the experiment (Day 29), as measured using HPLC. Letters indicate statistical differences at $\mathrm{p}<0.05 ; \mathrm{n}=3$ for each system, reported are means \pm SD. Sediment chl a cores were taken while mixing was on, and we only briefly turned off the mixing to collect the sample. NR: non-resuspension tanks; $\mathrm{R}$ : resuspension tanks 


\section{Macroinfauna and mesozooplankton}

The sediment was defaunated at the start of the experiment, and no macroinfauna developed in the $\mathrm{R}$ tanks over the course of the experiment. However, a macroinfauna community developed in the NR tanks with about $256 \pm 53$ ( $\mathrm{n}=6$ cores) nereid polychaetes and $93 \pm 81$ ( $\mathrm{n}=3$ cores) amphipods per square meter by the end of the $4 \mathrm{wk}$ experiment (Day 29). The dominant mesozooplankton taxa found in the water column were adult Acartia spp. copepods, copepodites, copepod nauplii, and polychaete larvae (Fig. 9). Pumps likely destroyed the adult mesozooplankton stages

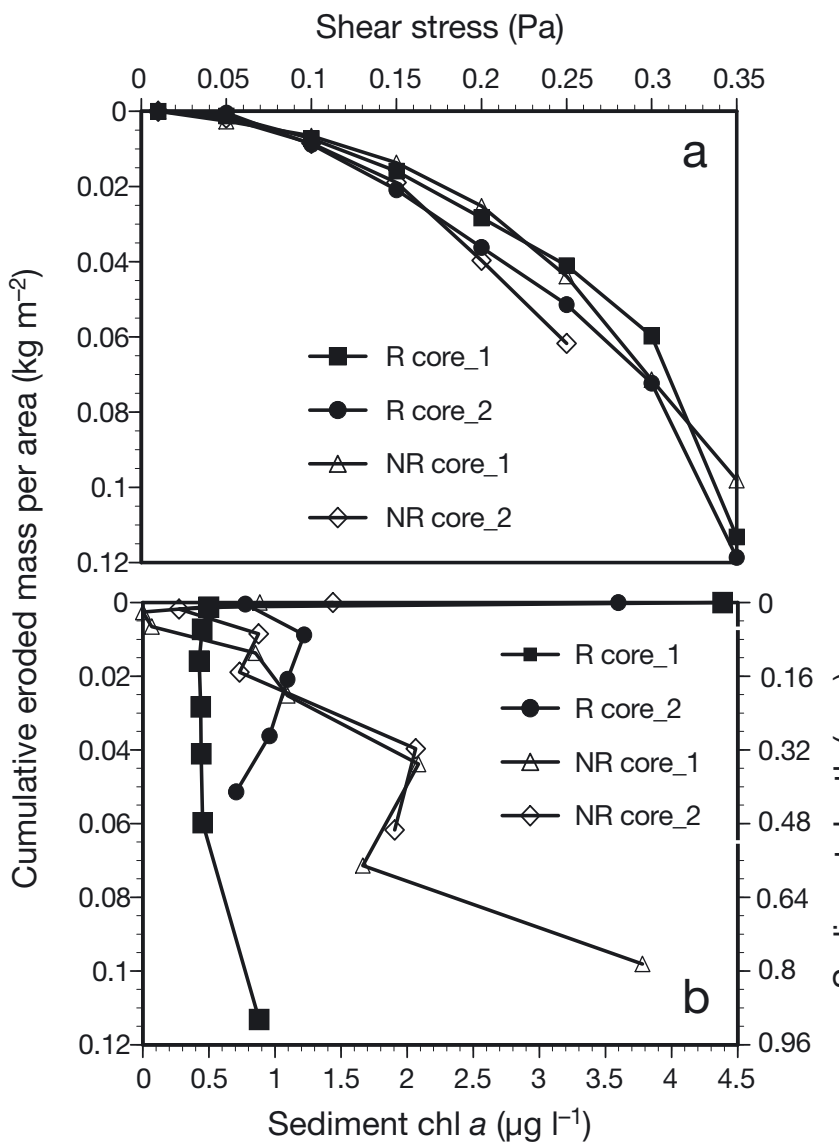

Fig. 7. (a) Eroded mass of sediment from sediment cores from the non-resuspension (NR) and resuspension (R) tanks subjected to 8 stepwise increases in bottom shear stress in duplicate $10 \mathrm{~cm}$ diameter Gust microcosm cores. Samples for Core 2 from the NR tanks for shear stress steps 0.3 and 0.35 Pa were lost. (b) Erosion of sediment chlorophyll a (chl a) from the NR and $\mathrm{R}$ tanks subjected to stepwise increases in bottom shear stress in duplicate $10 \mathrm{~cm}$ diameter Gust microcosm cores. The $y$-axis on the right depicts the approximate depth of the eroded layer after making some assumptions concerning sediment porosity and sediment density (see 'Results'). Eroded mass and depth are synonymous. For Core 2 of the $\mathrm{R}$ systems for shear stress steps 0.3 and $0.35 \mathrm{~Pa}$, chl a data were lost. The erosion cores were collected after the water column had been quiescent for some time, and high surface chl $a$ values indicate settled phytoplankton
(Adey \& Loveland 1998) during the initial raw water fill of the tanks at the start of the experiment, and it took about 2 wk until adult copepods and polychaete larvae were abundant (Fig. 9). The NR tanks contained about 60 adult Acartia sp. $\mathrm{l}^{-1}$ by the end of the experiment, while the $\mathrm{R}$ tanks contained only about 20 adult Acartia spp. $\mathrm{l}^{-1}$. On the other hand, about 25 polychaete larvae $\mathrm{l}^{-1}$ were found in the $\mathrm{R}$ tanks over the last $2 \mathrm{wk}$ of the experiment (Fig. 9d), whereas only about 1 polychaete larvae $1^{-1}$ was found in the NR tanks (Fig. 9d), even though there were adult polychaetes in the sediment. Copepodite and copepod nauplius abundances were not significantly different between systems (Table 1g, Fig. 9). As shown by the negative correlation of water-column chl $a$ and mesozooplankton biomass (both in carbon units), the increasing abundance of mesozooplankton negatively affected phytoplankton biomass in the NR tanks (Fig. 9e), which may partially explain the lower phytoplankton levels in the NR tanks.

\section{Nitrogen budget}

Zooplankton, phytoplankton biomass, microphytobenthos, DIN, DON, and porewater resuspension were included in the nitrogen budget. The data in Table 3 suggest that tidal resuspension significantly affected nitrogen partitioning within the system. Overall, about $9 \%$ more nitrogen was accumulated in the $\mathrm{R}$ tanks than in the NR tanks (192 vs. $174 \mathrm{mmol} N$ ). While the NR tanks were benthic-dominated systems, with $54 \%$ of the nitrogen partitioned into microphytobenthos, the $\mathrm{R}$ tanks were water-column-dominated, with $86 \%$ of the nitrogen partitioned into different water-column components (phytoplankton, zooplankton, TDN). Overall, the total fraction of the nitrogen in algae, either phytoplankton or microphytobenthos, was similar for both systems (85\% in the NR tanks; $88 \%$ in the $\mathrm{R}$ tanks). However, the fractions of algae partitioned differently, where the majority partitioned into microphytobenthos in the NR tanks and into phytoplankton in the $\mathrm{R}$ tanks. The major nitrogen inputs were due to daily water exchanges and benthic fluxes. The daily water exchange inputs were identical between the $\mathrm{R}$ and the NR tanks. Diffusive nitrogen fluxes were similar between the $\mathrm{R}$ and the NR tanks (Fig. 8b-d); thus, the benthic nitrogen fluxes were only slightly higher in the $\mathrm{R}$ systems due to porewater resuspension. Very little microphytobenthos in the $\mathrm{R}$ tanks was resuspended. However, some phytoplankton $\mathrm{N}$ was exported during the daily exchange in the $\mathrm{R}$ tanks.

Porewater $\mathrm{N}$ release due to resuspension was estimated using measured porewater ammonium concentrations from the upper sediment section $(0-5 \mathrm{~mm})$ 
( $40 \mathrm{\mu mol} \mathrm{l}^{-1}$; Porter et al. 2006) and using the assumed porosity of 0.95 . Overall, $76 \mu \mathrm{mol}$ of ammonium is released to the $1000 \mathrm{l}$ water column per resuspension cycle. Assuming replenishment with ammonium during each off phase (a conservative assumption) and including oxidized nitrogen in the benthic flux estimations (Fig. 8c), then porewater resuspension enhanced the $\mathrm{R}$ tank nitrogen concentration by about $0.5 \mu \mathrm{mol} \mathrm{l}^{-1}$ $\mathrm{d}^{-1}$. This is equivalent to an additional efflux rate of $490 \mu \mathrm{mol} \mathrm{m} \mathrm{m}^{-2} \mathrm{~d}^{-1}$, approximately 20 to $25 \%$, over the diffusional flux measured in the benthic flux chambers (Fig. 8d). Thus, porewater release due to resuspension is at most a small additional source of nitrogen to the system. In sandy sediments, stirring can induce additional porewater release due to advective flushing (Huettel \& Gust 1992), but this is not the case with the muddy sediments used in this experiment.

Several variables were not included in the $\mathrm{N}$ budget. Sediment-water nitrogen flux rates were similar in both the NR and the R tanks and thus not included. Denitrification was not measured, and macrofauna $\mathrm{N}$ content was not determined. POC was estimated from POM and not measured directly; thus, phytoplankton biomass $\mathrm{N}$ and microphytobenthos $\mathrm{N}$ content in the $\mathrm{R}$ tanks used the POC:chl a relationship derived from the NR tanks (see above). Even with these limitations,
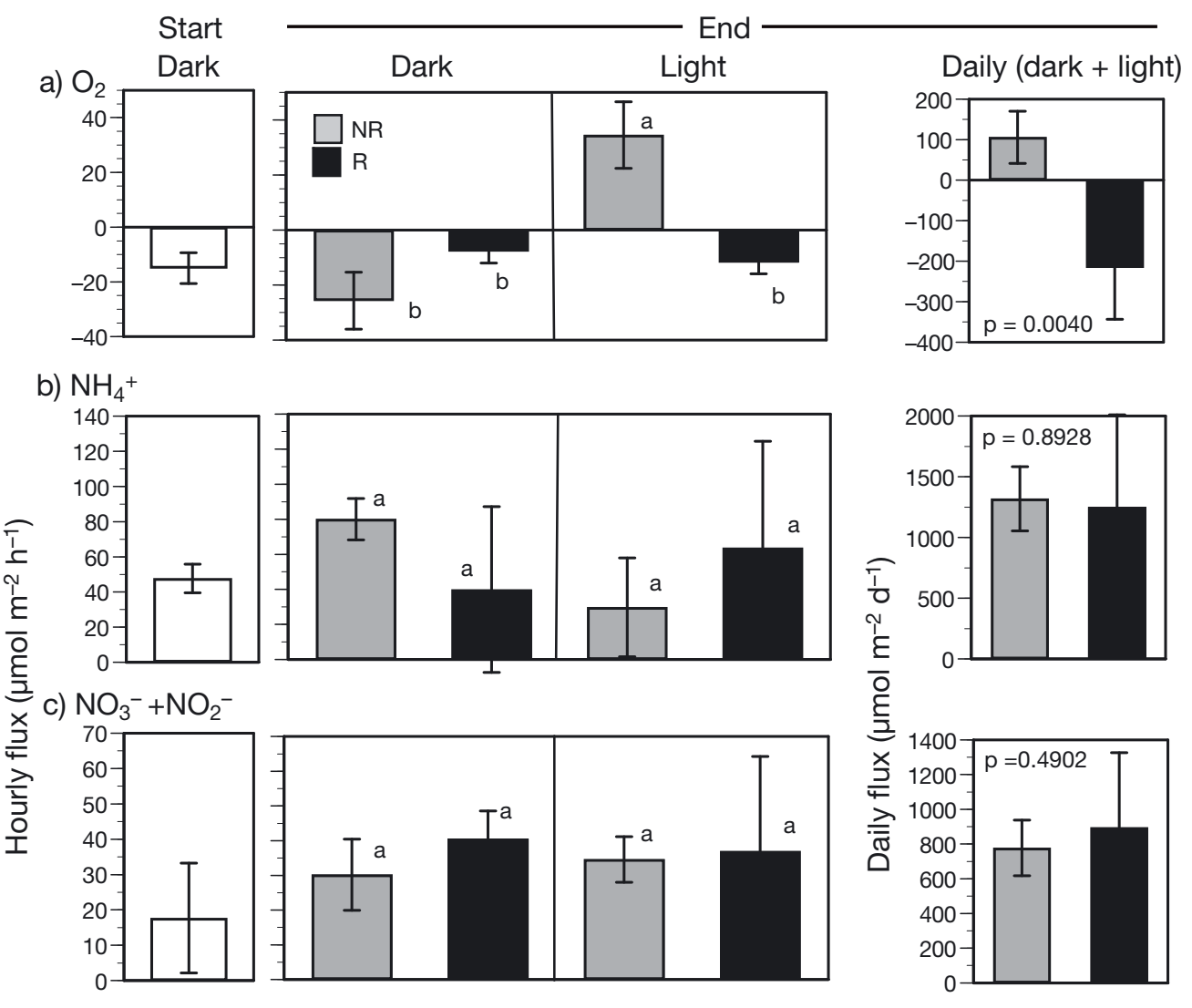

d) DIN
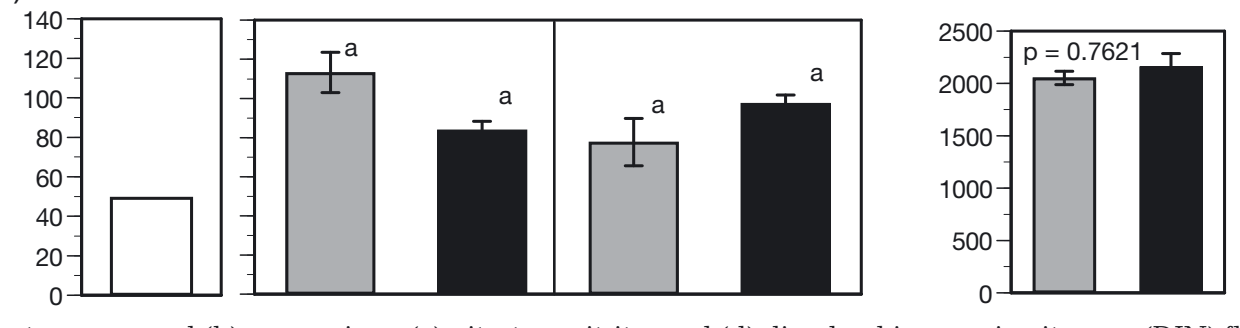

Fig. 8. (a) Sediment oxygen and (b) ammonium, (c) nitrate + nitrite, and (d) dissolved inorganic nitrogen (DIN) fluxes from sediment cores collected from the resuspension (R) and non-resuspension (NR) tanks; fluxes are mediated by microphytobenthos photosynthesis and macrofauna. Sediment fluxes were run in the dark and in the light; the daily fluxes were calculated after Kemp \& Cornwell (2001). 'Start' cores contained sediment from the start of the experiment see 'Results'), all other cores were collected at the end of the experiment. Letters indicate statistical differences at $\mathrm{p}<0.05 ; \mathrm{n}=3$ for each system;reported are means $\pm \mathrm{SD}$ 
Table 3 unmistakably shows the partitioning of nitrogen into the benthic and pelagic components, with the $\mathrm{R}$ tanks becoming pelagic-dominated and the NR tanks becoming benthic-dominated.

\section{DISCUSSION}

In our mesocosm experiments, tidal resuspension greatly affected overall water quality, the distribution of algae between the water column and microphytobenthos, and mesozooplankton dynamics.

Unexpectedly, phytoplankton biomass was significantly higher in the $\mathrm{R}$ tanks than in the NR tanks, although light was limited in the $\mathrm{R}$ tanks. Enhanced bottom stress and resuspension in the $\mathrm{R}$ tanks limited both light penetration to the bottom and microphytobenthos biomass. Light reached the sediments routinely in the NR tanks and allowed significantly greater microphytobenthos growth than in the R tanks, such that microphytobenthos were the dominant microalgae in the NR tanks. The core erosion studies showed that microphytobenthos were deeper in the sediments in the NR tanks than the thin veneer of settled phytoplankton at the sediment surface in the $\mathrm{R}$ tanks.

The enhanced phytoplankton levels in the $\mathrm{R}$ tanks were most likely due to higher inorganic nutrient levels. Nitrate + nitrite increases and decreases in the $\mathrm{R}$ tanks were followed by increases and decreases in phytoplankton biomass in the $\mathrm{R}$ tanks. This indicates the importance of inorganic nutrient concentrations in driving algal biomass. Partitioning of nitrogen between the R and NR systems was very different. The NR tanks were benthic-dominated, with high microphytobenthos biomass, while the $\mathrm{R}$ tanks were watercolumn-dominated, with more phytoplankton and more degraded algae (phaeophytin).

Effects of sediment resuspension on nutrient dynamics have been noted previously. In a $4.5 \mathrm{~d}$ long experiment with grid-stirred 2.61 benthic chambers, Garstecki et al. (2002) found that sediment resuspension increased nutrient concentrations and affected the dynamics of a coastal planktonic microbial food web. Oertel \& Dunstan (1981) found enhanced nutrient concentrations in turbid environments and higher phytoplankton biomass in a Georgia embayment, as did Lawrence et al. (2004), who found that wind-resuspended bottom material correlated with increased nutrients in the water. Tengberg et al. (2003) found that sediment resuspension (generated in flux chambers), decreased oxygen fluxes, increased nitrate + nitrite fluxes, but had no effect on ammonium fluxes. Grémare et al. (2003) found enhanced nutrient concentrations after a major storm event.
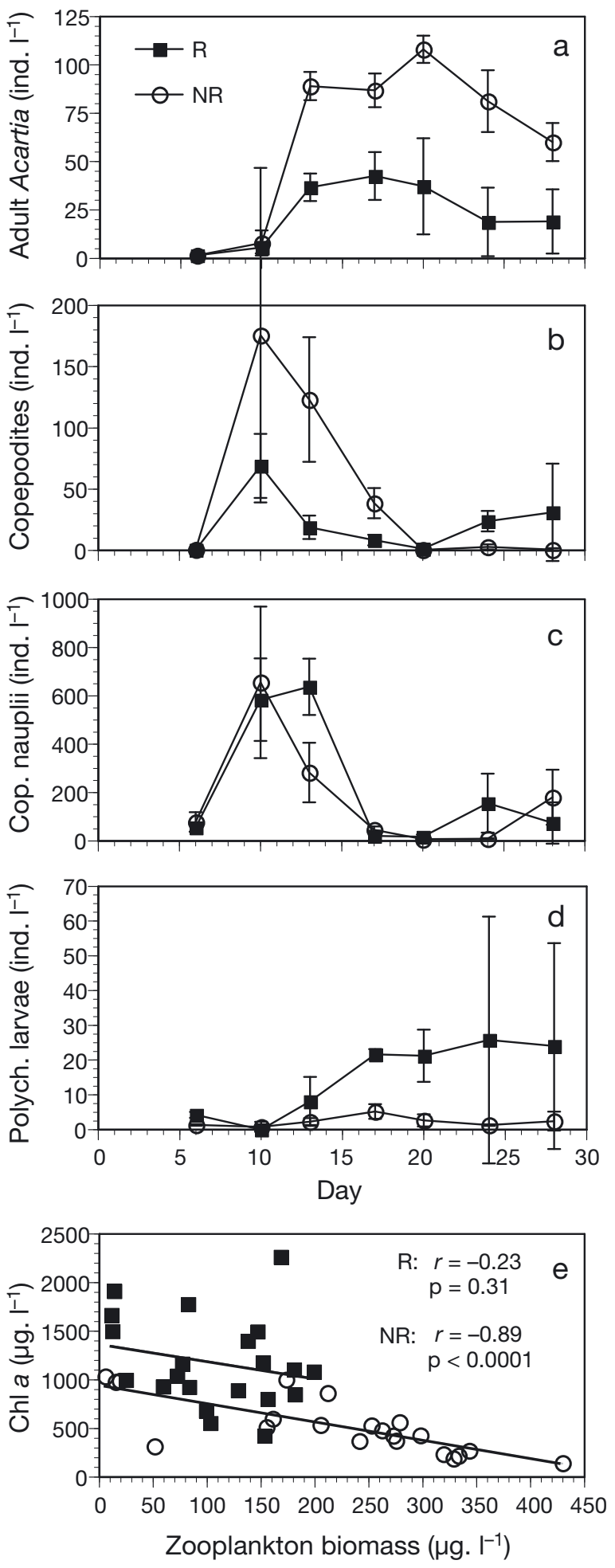

Fig. 9. Mesozooplankton abundance over the experiment for: (a) adult Acartia sp., (b) copepodites, (c) copepod (cop.) nauplii, and (d) polychaete (polych.) larvae; $\mathrm{n}=3$, reported are means \pm SD. (e) Relationship of phytoplankton biomass and the biomass of the mesozooplankton community (common carbon unit, Panels a to d included) in the resuspension (R) and non-resuspension (NR) tanks, respectively. For statistical results see Table $1 \mathrm{~g}, \mathrm{~h}$ 
Table 3. Partitioning of nitrogen $(\mathrm{N})$ within the resuspension (R) and nonresuspension (NR) tanks (see 'Results'). DIN: dissolved inorganic nitrogen (ammonium + nitrate + nitrite); DON: dissolved organic nitrogen

\begin{tabular}{|lcccc|}
\hline & $\begin{array}{c}\mathrm{R} \\
(\mu \mathrm{mol} \mathrm{N})\end{array}$ & $\begin{array}{c}\text { Distribution } \\
\text { within R }(\%)\end{array}$ & $\begin{array}{c}\mathrm{NR} \\
(\mu \mathrm{mol} \mathrm{N})\end{array}$ & $\begin{array}{c}\text { Distribution } \\
\text { within NR }(\%)\end{array}$ \\
\hline Zooplankton N & 1777 & 0.9 & 3684 & 2.1 \\
Phytoplankton N & 142448 & 74.3 & 53141 & 30.6 \\
Microphytobenthos N & 26061 & 13.6 & 94322 & 54.3 \\
DIN & 5074 & 2.6 & 2832 & 1.6 \\
DON & 15998 & 8.3 & 19666 & 11.3 \\
Porewater N & 490 & 0.3 & 0 & 0 \\
Total N & 191848 & 100 & 173645 & 100 \\
Imbalance of nitrogen between R and NR: $18203 \mu \mathrm{mol} \mathrm{N}$ & \\
\hline
\end{tabular}

Elevated concentrations of brown tide organisms (Aureococcus anophagefferens), as detected with the but-fuco marker pigment (Trice et al. 2004) when gyroxanthin diester and 19'hexanoyloxyfucoxanthin were absent, were found in the R tanks but not in the NR tanks and even reached bloom conditions. Thus, tidal resuspension stimulated an $A$. anophagefferens abundance. In addition, while $A$. anophagefferens increased to bloom conditions on Day 25, cyanobacteria decreased dramatically in the $\mathrm{R}$ tanks.

The growth of $A$. anophagefferens may have been stimulated by the higher dissolved nutrient concentrations (nitrate + nitrite, $\mathrm{DIN}, \mathrm{PO}_{4}{ }^{3-}$ ). The conditions in the R tanks, a mixture of DIN and DON and low light, may have favored the growth of brown tide algae, as has been suggested by Pustizzi et al. (2004). In addition, MacIntyre et al. (2004) suggested that A. anophagefferens is likely to bloom when high turbidity provides refuge from irradiance and that $A$. anophagefferens is a better competitor under low light conditions. Moreover, MacIntyre et al. (2004, their Fig. 8) presented a model comparing the effect of low versus high energy environments on triggering $A$. anophagefferens blooms, whereby the model was primarily driven by light and nutrient availability, as mediated by resuspension.

Dissolved organic nutrient concentrations (DON, DOP) were significantly higher in the NR tanks than in the $\mathrm{R}$ tanks, but these did not appear to enhance general phytoplankton biomass. This is consistent with the general understanding that plants use only inorganic nutrients and not the organic forms. However, DON concentrations decreased at a faster rate in the $\mathrm{R}$ than in the NR tanks, perhaps due to the ability of brown tide algae to use a mixture of DIN and DON (Pustizzi et al. 2004). Marshall et al. (2005) also reported Aureococcus anophagefferens in Chesapeake Bay water and recognized that another 'association within the changing trophic status of the [Chesapeake] Bay estuary was the increased recognition of potentially toxic species in these waters' (p. 1100).
We found significant differences in the mesozooplankton community structure between the R and NR tanks. Polychaete larvae became significantly more abundant in the R tanks and likely selectively grazed the diatoms and/or chrysophytes, shifting the population towards cyanobacteria in the NR tanks. In other experiments with defaunated sediments, the sediments stayed devoid of macroinfauna until the end of the $4 \mathrm{wk}$ in experiments (Porter et al. $2004 a, b)$. In the present experiments, however, we found a macroinfaunal community composed of polychaetes and amphipods in the NR tanks, but not in the R tanks. This may be because the low bottom stress, and thus the stable sedimentary bottom, allowed polychaete larvae to recruit to the bottom of the NR tanks and grow. In contrast, polychaete larvae were not able to recruit to the unstable sedimentary bottom of the R tanks, as has been previously shown for larvae (Thrush et al. 1996). Crimaldi et al. (2002) also found that instantaneous turbulence and water flow affects larval settlement. High shear stress can erode larvae from surfaces (Koehl \& Hadfield 2004).

The mesozooplankton community was negatively correlated with phytoplankton biomass in the NR tanks (Fig.9e). These estimates do not include any potential grazing effects of the microzooplankton community, which we did not measure. Others have shown that benthic boundary-layer flow can increase microzooplankton abundance and have suggested that resuspension of protists may alter the microbial food web (Shimeta et al. 2003), all of which may have selectively affected microzooplankton grazing in the R tanks. However, Lawrence et al. (2004) found that resuspension decreased microzooplankton abundance.

In complex ecosystems, multiple direct and indirect pathways are likely to be operating simultaneously, potentially reinforcing or cancelling each other's overall effects (Wootton 2002) and confounding interpretation of experimental results. For example, light penetration to the sediments, in interaction with bottom shear velocity (Porter et al. 2004a,b), nutrient availability (Sundbäck et al. 2000), and macrofaunal grazing (Muschenheim \& Newell 1992, Herman et al. 2000), all may have directly mediated microphytobenthos abundance in our experiments, but were produced through indirect interactions. Adult polychaetes, which were very active during our flux experiments, and amphipods in the NR systems offset the positive effects of microphytobenthos in nutrient uptake by increasing nutrient fluxes through bioirrigation and 
bioturbation (Kristensen 1984, Pelegrí et al. 1994), thereby canceling out any positive effects of microphytobenthos on water quality. Thus, models and studies that consider how water-column depth and light penetration directly affect microphytobenthos and water quality (Robson \& Webster 2006) should be expanded to also include interaction modifications that may be inadvertently introduced through resuspension and similar aspects of realistic ecosystem complexity.

Indirect effects have often been identified by accident when experiments produced unanticipated results (Wooten 2002). In the present case, phytoplankton growth was driven by 2 factors, light limitation and nutrients. This was initially unanticipated as our initial hypotheses had focused only on the effect of light limitation due to resuspension on phytoplankton growth. However, resuspension also relaxed nutrient limitation, which dominated the effects of increasing light limitation. Thus, the R tanks were light-limited, but higher inorganic nutrient levels associated with resuspension, coupled with lower zooplankton feeding, resulted in higher phytoplankton biomass.

Major functional changes were brought about by one key variable, resuspension. Resuspension mechanistically functioned like a switch, excluding benthic fauna, reducing microphytobenthos biomass, resuspending porewater nutrients, desorbing nutrients from particles, enhancing nutrient concentrations, and increasing phytoplankton concentrations. Resuspension has been found to be important in field studies in shallow-water environments; however, causal relationships and interaction modifications are difficult to discern in the field. Short-term, bench-scale experiments do not include interaction modifications due to indirect effects. However, our mesocosm experiments make it clear that resuspension is a key environmental factor that must be considered and included in ecosystem experiments that address benthic-pelagic coupling in shallow-water systems. Resuspension in nature occurs on a regular basis through tidal action and through episodic events such as storms. The effects of changing frequencies and magnitudes of resuspension on shallow-water ecosystems need more attention and provide a rich area for future research.

Acknowledgements. We thank Heather Soulen, Eun-Hee Kim, and summer student Melissa Bonner for help with this experiment. We thank Heather Soulen for processing the zooplankton samples, and Patrick Dickhudt for running the Gust microcosm core erosion experiments. Giselher Gust, Technische Universität Hamburg-Harburg, Germany, kindly permitted us to use $10 \mathrm{~cm}$ diameter microcosms for the core erosion experiments. The Chesapeake Biological Laboratory and Horn Point Laboratory Analytical Services Departments analyzed many samples, and the Chesapeake Biological Laboratory, University of Maryland Center for Environmental Science (UMCES), provided space to set up the mesocosm facility. Tom Fisher provided helpful advice for the interpretation of nutrient limitation, and the crew of the RV 'Aquarius' helped us collect the sediments. We appreciate the careful review and suggestions by 3 anonymous reviewers that greatly improved the manuscript. This research was supported by Grant R 824850-01-0 from the United States Environmental Protection Agency Science To Achieve Results (EPA STAR) program as part of the Multiscale Experimental Ecosystem Research Center (MEERC) at UMCES, by Grant 35236 by the Hudson River Foundation to R.P.M., E.T.P., and L.P.S. This is a publication of Washington College and UMCES Contribution No. 4445.

\section{LITERATURE CITED}

Aberle J, Nikora V, Walters R (2004) Effects of bed material properties on cohesive sediment erosion. Mar Geol 207: 83-93

Adey WH, Loveland K (1998) Pumps. In: Adey WH, Loveland $\mathrm{K}$ (eds) Dynamic aquaria. Building living ecosystems. Academic Press, San Diego, CA, p 27-33

> Andersen TJ (2001) Seasonal variation in erodibility of two temperate, microtidal mudflats. Estuar Coast Shelf Sci 53: $1-12$

Baker JE, Mason RP, Cornwell JC, Ashley J, Halka J, Hill J (1997) Spatial mapping of sedimentary contaminants in the Baltimore Harbor/Patapsco River/Back River system. Final report to the Maryland Department of the Environment. University of Maryland Center for Environmental Science/Chesapeake Biological Laboratory, Solomons, MD, p 97-142

Berg JA, Newell RIE (1986) Temporal and spatial variations in the composition of seston available to the suspension feeder Crassostrea virginica. Estuar Coast Shelf Sci 23: 375-386

Blackford JC (2002) The influence of microphytobenthos on the northern Adriatic ecosystem: a modelling study. Estuar Coast Shelf Sci 55:109-123

> Blanchard GF, Sauriau PG, Cariou-Le Gall V, Gouleau D, Garet MJ, Olivier F (1997) Kinetics of tidal resuspension of microbiota: testing the effects of bioturbation using flume experiments. Mar Ecol Prog Ser 151:17-25

Chang ML, Sanford LP (2005) Modeling the effects of tidal resuspension and deposition on early diagenesis of contaminants. Aquat Ecosyst Health Manag 8:41-51

Chang J, Shiah FK, Gong GC, Chiang KP (2003) Cross-shelf variation in carbon-to-chlorophyll a ratios in the East China sea, summer 1998. Deep-Sea Res II 50:1237-1247

Chen CC, Petersen JE, Kemp WM (1997) Spatial and temporal scaling of periphyton growth on walls of estuarine mesocosms. Mar Ecol Prog Ser 155:1-15

Crawford SM, Sanford LP (2001) Boundary shear velocities and fluxes in the MEERC experimental ecosystems. Mar Ecol Prog Ser 210:1-12

Crimaldi JP, Thompson JK, Rosman JH, Lowe RJ, Koseff JR (2002) Hydrodynamics of larval settlement: the influence of turbulent stress events at potential recruitment sites. Limnol Oceanogr 47:1137-1151

> Davis WR (1993) The role of bioturbation in sediment resuspension and its interaction with physical shearing. J Exp Mar Biol Ecol 171:187-200

> Dickhudt, PJ, Friedrichs CT, Schaffner LC, Sanford LP (2009) Spatial and temporal variation in cohesive sediment erodibility in the York River estuary: a biologically-influenced equilibrium modified by seasonal deposition. Mar Geol 267:128-140

Fanning KA, Carder KL, Betzer PR (1982) Sediment resuspen- 
sion by coastal waters: a potential mechanism for nutrient re-cycling on the ocean's margins. Deep-Sea Res 29: 953-965

Fisher TR, Peele ER, Ammerman JW, Harding LW Jr (1992) Nutrient limitation of phytoplankton in Chesapeake Bay. Mar Ecol Prog Ser 82:51-63

- Fisher TR, Gustafson AB, Sellner K, Lacouture R and others (1999) Spatial and temporal variation of resource limitation in Chesapeake Bay. Mar Biol 133:763-778

Garstecki T, Wickham SA, Arndt H (2002) Effects of experimental sediment resuspension on a coastal planktonic microbial food web. Estuar Coast Shelf Sci 55:751-762

Geider RJ (1987) Light and temperature dependence of the carbon to chlorophyll a ratio in microalgae and cyanobacteria: implications for physiology and growth of phytoplankton. New Phytol 106:1-34

Grant WD, Madsen OS (1979) Combined wave and current interaction with a rough bottom. J Geophys Res 84: 1797-1808

Grémare A, Amouroux JM, Cauwet G, Charles F and others (2003) The effects of a strong winter storm on physical and biological variables at a shelf site in the Mediterranean. Oceanol Acta 26:407-419

Guillén J, Jiménez JA, Palanques A, Gracia V, Puig P, Sánchez-Arcilla A (2002) Sediment resuspension across a microtidal, low-energy inner shelf. Cont Shelf Res 22: 305-325

Gust G (1988) Skin friction probes for field applications. JGeophys Res 93:14,121-14,132

Gust G, Müller V (1997) Interfacial hydrodynamics and entrainment functions of currently used erosion devices. In: Burt N, Parker R, Watts J (eds) Cohesive sediments. John Wiley and Sons, Chichester, p 149-174

Harding LW, Mallonee ME, Perry ES (2002) Toward a predictive understanding of primary productivity in a temperate, partially stratified estuary. Estuar Coast Shelf Sci 55: 437-463

Herman PMJ, Middelburg JJ, Widdows J, Lucas CH, Heip CHR (2000) Stable isotopes as trophic tracers: combining field sampling and manipulative labelling of food resources for macrobenthos. Mar Ecol Prog Ser 204:79-92

Heyes A, Miller C, Mason RP (2004) Mercury and methylmercury in Hudson River sediment: impact of tidal resuspension on partitioning and methylation. Mar Chem 90:75-89

Huettel M, Gust G (1992) Solute release mechanisms from confined sediment cores in stirred benthic chambers and flume flows. Mar Ecol Prog Ser 82:187-197

Jeffrey SW, Vesk M (1997) Introduction to marine phytoplankton and their pigment signatures In: Jeffrey SW, Mantoura RFC, Wright SW (eds) Phytoplankton pigments in oceanography: guidelines to modern methods, Vol 10. Monographs on oceanographic methodology. UNESCO Publishing, Paris, p 74-75, Table 2.3

Jørgensen SE, Patten BC, Straškraba M (1992) Ecosystems emerging-toward an ecology of complex-systems in a complex future. Ecol Modell 62:1-27

Keefe CW, Blodnikar KL, Boynton WR, Clark CA and others (2004) Nutrient analytical services laboratory standard operating procedures. Special Publication Series No. SS-80-04-CBL, Chesapeake Biological Laboratory, University of Maryland Center for Environmental Science, Solomons, MD. Available at: http://archive.chesapeakebay.net/pubs/quality_assurance/CBL_NASL_SOP_Feb_ 2004.pdf (accessed on 14 June 2010)

Kemp WM, Cornwell JC (2001) Role of benthic communities in the cycling and balance on nitrogen in Florida Bay. Final report to USEPA, UMCES TS-351-03. University of Maryland Center for Environmental Science, Cambridge, MD
Kirk JTO (1994) Light and photosynthesis in aquatic ecosystems. Cambridge University Press, Cambridge

Koehl MAR, Hadfield MG (2004) Soluble settlement cue in slowly moving water within coral reefs induces larval adhesion to surfaces. J Mar Syst 49:75-88

- Kristensen E (1984) Effect of natural concentrations of nutrient exchange between a polychate burrow in estuarine sediment and the overlying water. J Exp Mar Biol Ecol 75: $171-190$

Krivtsov V (2004) Investigations of indirect relationships in ecology and environmental sciences: a review and the implications for comparative ecosystem analysis. Ecol Modell 174:37-54

> Lawrence D, Dagg MJ, Liu HB, Cummings SR, Ortner PB, Kelble C (2004) Wind events and benthic-pelagic coupling in a shallow subtropical bay in Florida. Mar Ecol Prog Ser 266:1-13

Maa JPY, Sanford LP, Halka JP (1998) Sediment resuspension characteristics in Baltimore Harbor, Maryland. Mar Geol 146:137-145

> MacIntyre HL, Geider RJ, Miller DC (1996) Microphytobenthos: the ecological role of the 'Secret Garden' of unvegetated, shallow-water marine habitats. I. Distribution, abundance and primary production. Estuaries 19:186-201

> MacIntyre HL, Lomas MW, Cornwell JC, Suggett DJ, Gobler CJ, Koch EW, Kana TM (2004) Mediation of benthicpelagic coupling by microphytobenthos: an energy- and material-based model for initiation of blooms of Aureococcus anophagefferens. Harmful Algae 3:403-437

Marshall HG (1994) Chesapeake Bay phytoplankton. I. Composition. Proc Biol Soc Wash 107:573-585

Marshall HG, Burchardt L, Lacouture R (2005) A review of phytoplankton composition within Chesapeake Bay and its tidal estuaries. J Plankton Res 27:1083-1102

Meadows PS, Tait J (1989) Modification of sediment permeability and shear strength by two burrowing invertebrates. Mar Biol 101:75-82

> Meybeck M, Laroche L, Dürr HH, Syvitski JPM (2003) Global variability of daily total suspended solids and their fluxes in rivers. Global Planet Change 39:65-93

> Montoya JM, Pimm SL, Solé RV (2006) Ecological networks and their fragility. Nature 442:259-264

> Morin J, Morse JW (1999) Ammonium release from resuspended sediments in the Laguna Madre estuary. Mar Chem 65:97-110

> Muschenheim DK, Newell CR (1992) Utilization of seston flux over a mussel bed. Mar Ecol Prog Ser 85:131-136

> Oertel GF, Dunstan WM (1981) Suspended-sediment distribution and certain aspects of phytoplankton production off Georgia, USA. Mar Geol 40:171-197

Parsons TR, Maita Y, Lalli CM (1984) A manual of chemical and biological methods for seawater analysis. Pergamon, Oxford University Press, Oxford

> Pelegrí SP, Nielsen LP, Blackburn TH (1994) Denitrification in estuarine sediment stimulated by the irrigation activity of the amphipod Corophium volutator. Mar Ecol Prog Ser 105:285-290

Petersen JE, Sanford LP, Kemp WM (1998) Coastal plankton responses to turbulent mixing in experimental ecosystems. Mar Ecol Prog Ser 171:23-41

Porter ET (1999) Physical and biological scaling of benthicpelagic coupling in experimental ecosystem studies. $\mathrm{PhD}$ thesis, Marine Estuarine Environmental Sciences Program, University of Maryland, College Park, MD

Porter ET, Sanford LP, Suttles SE (2000) Gypsum dissolution is not a universal integrator of 'water motion'. Limnol Oceanogr 45:145-158 
Porter ET, Sanford LP, Gust G, Porter FS (2004a) Combined water column mixing and benthic boundary-layer flow in mesocosms: key for realistic benthic-pelagic coupling studies. Mar Ecol Prog Ser 271:43-60

> Porter ET, Cornwell JC, Sanford LP, Newell RIE (2004b) Effect of oysters Crassostrea virginica and bottom shear velocity on benthic-pelagic coupling and estuarine water quality. Mar Ecol Prog Ser 271:61-75

Porter ET, Owens M, Cornwell JC (2006) Effect of sediment manipulation on the biogeochemistry of experimental sediment systems. J Coast Res 22:1539-1551

Pustizzi F, Mac H, Intyre H, Warner ME, Hutchins DA (2004) Interaction of nitrogen source and light intensity on the growth and photosynthesis of the brown tide alga Aureococcus anophagefferens. Harmful Algae 3:343-360

Robson BJ, Webster IT (2006) Representing the effects of subgrid-scale variations in bathymetry on light and primary production. Environ Model Softw 21:802-811

Sanford LP (1997) Turbulent mixing in experimental ecosystem studies. Mar Ecol Prog Ser 161:265-293

Sanford LP (2008) Modeling a dynamically varying mixed sediment bed with erosion, deposition, bioturbation, consolidation, and armoring. Comput Geosci 34:1263-1283

Sanford LP, Suttles S, Porter ET (2009) Physical factors: mixing and flow. In: Petersen JE, Kennedy VS, Dennison WC, Kemp WM (eds) Enclosed experimental ecosystems and scale. Springer Verlag, New York, NY, p 63-74

Sanford LP, Panageotou W, Halka JP (1991) Tidal resuspension of sediments in northern Chesapeake Bay. Mar Geol 97:87-103

Schneider AR, Porter ET, Baker JE (2007) Polychlorinated biphenyl release from resuspended Hudson River sediment. Environ Sci Technol 41:1097-1103

Schoellhamer DH (1995) Sediment resuspension mechanisms in Old-Tampa Bay, Florida. Estuar Coast Shelf Sci 40: $603-620$

Schoellhamer DH (2002) Variability of suspended-sediment concentration at tidal to annual time scales in San Francisco Bay, USA. Cont Shelf Res 22:1857-1866

Shimeta J, Amos CL, Beaulieu SE, Katz SL (2003) Resuspension of benthic protists at subtidal coastal sites with differing sediment composition. Mar Ecol Prog Ser 259: $103-115$

Sondergaard M, Kristensen P, Jeppesen E (1992) Phosphorus release from resuspended sediment in the shallow and wind-exposed Lake Arresoe, Denmark. Hydrobiologia 228:91-99

> Steele JH, Baird IE (1965) The chlorophyll a content of particulate organic matter in the northern North Sea. Limnol Oceanogr 10:261-267

Sundbäck K, Miles A, Göransson E (2000) Nitrogen fluxes, denitrification and the role of microphytobenthos in microtidal shallow-water sediments: an annual study. Mar Ecol Prog Ser 200:59-76

Tengberg A, Almroth E, Hall P (2003) Resuspension and its effects on organic carbon recycling and nutrient exchange in coastal sediments: in situ measurements using new experimental technology. J Exp Mar Biol Ecol 285/286: 119-142

Tennekes H, Lumley JL (1972) A first course in turbulence, 15th edn. The MIT Press, Cambridge, MA

- Thomsen L, Gust G (2000) Sediment erosion thresholds and characteristics of resuspended aggregates on the western

Editorial responsibility: Graham Savidge,

Portaferry, UK
European continental margin. Deep-Sea Res I 47: 1881-1897

Thrush SF, Whitlatch RB, Pridmore RD, Hewitt JE, Cummings VJ, Wilkinson MR (1996) Scale-dependent recolonization: the role of sediment stability in a dynamic sandflat habitat. Ecology 77:2472-2487

> Trefry JH, Metz S, Nelson TA, Trocine RP, Eadie BJ (1994) Transport of particulate organic carbon by the Mississippi River and its fate in the Gulf of Mexico. Estuaries 17: 839-849

> Trice TM, Glibert PM, Lea C, Van Heukelem L (2004) HPLC pigment records provide evidence of past blooms of Aureococcus anophagefferens in the coastal bays of Maryland and Virginia, USA. Harmful Algae 3:295-304

> Tsai CH, Lick W (1986) A portable device for measuring sediment resuspension. J Gt Lakes Res 12:314-321

Van Heukelem L, Thomas CS (2001) Computer-assisted highperformance liquid chromatography method development with applications to the isolation and analysis of phytoplankton pigments. J Chromatogr A 910:31-49

Van Heukelem L, Thomas CS (2005) The HPL method, Chap 5. In: Hooker SB, Van Heukelem L, Thomas CS, Claustre $\mathrm{H}$ and others (eds) The second SeaWiFs HPLC Analysis Round Robin Experiment (SeaHARRE-2). NASA/TM2005-212785, Washington, DC, p 88-89, Table 50

Wainright SC (1990) Sediment-to-water fluxes of particulate material and microbes by resuspension and their contribution to the planktonic food web. Mar Ecol Prog Ser 62: 271-281

> Wainright SC, Hopkinson CS (1997) Effects of sediment resuspension on organic matter processing in coastal environments: a simulation model. J Mar Syst 11:353-368

Welschmeyer NA (1994) Fluorometric analysis of chlorophyll $a$ in the presence of chlorophyll $b$ and phaeopigments. Limnol Oceanogr 39:1985-1992

> White JR, Roman MR (1992) Seasonal study of grazing by metazoan zooplankton in the mesohaline Chesapeake Bay. Mar Ecol Prog Ser 86:251-261

- Willows RI, Widdows J, Wood RG (1998) Influence of an infaunal bivalve on the erosion of an intertidal cohesive sediment: a flume and modeling study. Limnol Oceanogr 43:1332-1343

> Wootton JT (2002) Indirect effects in complex ecosystems: recent progress and future challenges. J Sea Res 48: $157-172$

Wright SW, Jeffrey SW, Mantoura RFC (1997) Evaluation methods and solvents for pigment extraction. In: Jeffrey SW, Mantoura RFC, Wright SW (eds) Phytoplankton pigments in oceanography: guidelines to modern methods, Vol 10. Monographs on oceanographic methodology. UNESCO Publishing, Paris, p 261-282

Yallop ML, De Winder B, Paterson DM, Stal LJ (1994) Comparative structure, primary production and biogenic stabilization of cohesive and non-cohesive marine sediments inhabited by microphytobenthos. Estuar Coast Shelf Sci 39:565-582

Zimmermann CF, Keefe CW, Basche J (1997) EPA Method 440.0. Determination of carbon and nitrogen in sediments and particulates of estuarine/coastal waters using elemental analysis. National Exposure Research Laboratory, Office of Research and Development, US Environmental Protection Agency, Cincinnati, OH. Available at: www. epa.gov/microbes/m440_0.pdf (accessed 14 June 2010) 